\title{
3. IN-SITU STRUCTURE AND PROPERTIES OF 110-MA CRUST FROM GEOPHYSICAL LOGS IN DSDP HOLE 418A 1
}

\author{
Cristina Broglia and Daniel Moos, Lamont-Doherty Geological Observatory, Palisades, New York ${ }^{2}$
}

\begin{abstract}
DSDP Hole 418A, drilled through $324 \mathrm{~m}$ of sediments and $544 \mathrm{~m}$ of basalts during DSDP Legs 51-53 at the southern end of the Bermuda Rise, was reoccupied during ODP Leg 102 for the purpose of obtaining a comprehensive suite of geophysical logs. Although a hole restriction at $469 \mathrm{~m}$ below seafloor $(145 \mathrm{~m}$ into basement) prevented the recording of the complete log suite throughout the open-hole interval, two passes of the first Schlumberger tool combination, consisting of resistivity-sonic-gamma-ray-caliper, were recorded from just below the sediment/basalt interface at 324 to $788 \mathrm{mbsf}$. The remaining $80 \mathrm{~m}$ was not logged owing to the suspected presence of a logging tool and cable lost during DSDP Leg 53. The second Schlumberger lowering, consisting of compensated neutron porosity, natural gamma spectroscopy, and lithodensity, and the third lowering, dual resistivity laterolog and gamma ray, were both recorded in open hole from 464 to $788 \mathrm{mbsf}$. The second combination was also recorded through the pipe to the mud line. Careful calibration of these measurements in fresh flow basalts, corrections for known borehole effects, and comparison of gamma-ray results to core mineralogy result in an excellent set of physical-property measurements throughout the logged interval.

Differences in gamma-ray activity, mostly due to the potassium- 40 decay series, separate the basement interval into three zones on the basis of smectite content. The uppermost zone 1 consists of a series of relatively unaltered, low-porosity $(<15 \%)$, high $\mathrm{V}_{p}(>5 \mathrm{~km} / \mathrm{s})$ massive basalts and more porous lower velocity pillows capped by a 9 -m-thick, more highly altered pillow unit, the total extending from 324 to 388 mbsf (log lithologic Units 1 to 4 ). In zone 2, from 388 to 514 mbsf (log lithologic Unit 5 and Subunit 6A), the pillow basalts contain large amounts of smectite within fractures and voids; porosities generally range from $15 \%$ to $25 \%$, and velocities vary inversely with smectite content and porosity from 3.5 to $5 \mathrm{~km} / \mathrm{s}$. The bottom of the Subunit $6 \mathrm{~A}$ breccia at 514 mbsf marks a geophysical boundary separating these altered pillows from the much fresher pillows and flows of Subunit $6 \mathrm{~B}$ to Subunit $13 \mathrm{C}$ in the remainder of the logged interval, which we refer to as zone 3. In this zone velocities are generally above $4 \mathrm{~km} / \mathrm{s}$ and reach $6 \mathrm{~km} / \mathrm{s}$ in the massive flows. Porosities are generally below $20 \%$; smectite is generally less than $5 \%$. The density log is more sensitive to well-bore rugosity than the other logs, but aside from this effect, density ranges from 2.4 to $2.95 \mathrm{~g} / \mathrm{cm}^{3}$. After correction for the presence of smectite, density is generally inversely proportional to porosity, as expected in a two-phase (seawater-basalt) system.

Although velocities within the altered section (zone 2) are somewhat lower than in the remainder of the hole, nowhere are they as low as in seismic Layer $2 \mathrm{~A}$. In the uppermost $190 \mathrm{~m}$ of the basement where smectite is replaced by void space, the average velocity can be reduced to less than $3.5 \mathrm{~km} / \mathrm{s}$. Thus, alteration and smectite infilling over the $110 \mathrm{Ma}$ since the formation of these rocks can raise in-situ velocities and eliminate Layer $2 \mathrm{~A}$ as part of the crustal aging process.
\end{abstract}

\section{INTRODUCTION}

Historically, the two primary methods by which the physical properties of the oceanic crust have been determined are seismic-refraction surveys (e.g., Houtz and Ewing, 1976) and laboratory core measurements (e.g., Hamano, 1980; Christensen et al., 1980; Hyndman et al., 1984). Occasionally log results in basement were reliable enough that $i n$-situ physical properties could be determined (Kirkpatrick, 1979b; Anderson et al., 1985a, 1985b). Seismic surveys measure the average properties of the crust over a scale of hundreds of meters. Core measurements provide information about the recoverable material. Downhole measurements serve to tie these two data sets together by detailing the relationship between in-situ physical properties and the composition and structure of the materials, including largescale fractures and voids not sampled by coring.

With the improvement in logging technology and the new commitment to geophysical logging in the Ocean Drilling Program, downhole measurements are now routinely being made in

\footnotetext{
${ }^{1}$ Salisbury, M. H., Scott, J. H., et al., 1988. Proc. ODP, Sci. Results, 102: College Station, TX (Ocean Drilling Program).

2 Addresses: Borehole Research Group, Lamont-Doherty Geological Observatory of Columbia University, Palisades, NY 10964; (Moos, present address) Department of Geophysics, Stanford University, Stanford, CA 94305.
}

ODP boreholes. This paper presents detailed analyses of the first set of ODP wireline logs in basement, obtained in Deep Sea Drilling Project (DSDP) Hole 418A during ODP Leg 102. Our purpose is to show the sequence of steps necessary to obtain meaningful, accurate, and detailed lithostratigraphic measurements from logging data. By presenting the original data and documenting the steps taken to correct them for environmental effects and to calibrate the results using recovered cores, we hope to provide a general reference for the analysis of Schlumberger logs. We describe how the logging environment (hole size, wall roughness, and the presence of pipe in the hole) affects the log response and the corrections required before accurate physical properties can be obtained.

The results of this analysis demonstrate the advantage of a unified systematic approach to the determination of physical properties, which requires seismic data, accurate logs, and careful laboratory physical-property measurements. $\log$ results cannot be extrapolated blindly from the immediate vicinity of the hole. Due to the heterogeneous nature of oceanic basalts, logdetermined properties are representative of the range of properties encountered but do not necessarily reflect in-situ vertical zonations accurately, except in a statistical sense. However, combining seismic-refraction data, which grossly average crustal properties, with the much finer scaled log measurements significantly enhances the results of both techniques. Core data, although generally biased by inherent sampling problems, provide matrix properties useful for the calibration of the logs. 
Hole $418 \mathrm{~A}$, in a water depth of $5511 \mathrm{~m}$ at the southern end of the Bermuda Rise (Fig. 1), was drilled during DSDP Legs 5153 into $110-\mathrm{Ma}$ crust through $324 \mathrm{~m}$ of sediments and penetrated $544 \mathrm{~m}$ into oceanic Layer 2 basalts (Shipboard Scientific Parties, 1980b). A pair of companion holes (417A and 417D) were drilled 209 and $366 \mathrm{~m}$ into basement at a nearby site. At the time, the information collected at Sites 417 and 418 represented the most comprehensive set of in-situ physical-property data in the shallow oceanic crust.

Recovery in these holes was remarkably high, leading Salisbury et al. (1980b) to conclude that the in-situ distribution of flows and pillows was adequately represented by recovered core ( $71 \%$ pillows, $22 \%$ massive basalts, and $7 \%$ partially cemented basalt rubble). They further concluded, based on logs in Hole 417D and on the recovered material, that in the upper $0.5 \mathrm{~km}$ of Cretaceous crust open porosity and alteration products each represent about $5 \%$ of the in-situ volume. The average velocity of the uppermost basement was determined to be about $4.8 \mathrm{~km} / \mathrm{s}$, confirming Houtz and Ewing's (1976) conclusion that Layer 2A is not present in Atlantic crust older than about $60 \mathrm{Ma}$.

The new logging data collected during ODP Leg 102 provide a unique opportunity to compare the above results to in-situ porosity, density, velocity, resistivity, and spectral gamma ray logs obtained in Hole 418A.

\section{LOGGING DATA}

The upper part of the basement, from $788 \mathrm{~m}$ below seafloor (mbsf) to the sediment/basalt contact at $324 \mathrm{mbsf}$, was logged with electrical, nuclear, and sonic logs. The logging tools, provided by Schlumberger, consisted of LSS-DIL-GR-CALI (longspaced sonic/dual induction-spherically focused resistivity/natural gamma ray/caliper), DLL-GR (dual laterolog/natural gamma ray), and LDT-CNT-NGT (lithodensity/compensated neutron porosity/spectral gamma ray). A description of these tools and their specifications are provided in the "Site 418 " chapter (Shipboard Scientific Party, 1986). Only the sonic-resistivity-gammaray combination was run open-hole through the entire interval; the remaining logs were recorded open-hole from 788 to 464 mbsf and through the pipe up to the sediment/basement contact at 324 mbsf. In fact, because of a 12-m-thick hole constriction at 469 mbsf (caliper exhibits values less than 10 in., Fig. 2), it was necessary to lower the pipe a few meters below this depth to allow the tool string to get through the bridge and reach the bottom of the hole. Logs were not run from total depth $(868$ mbsf) because it was believed that a sonic tool and about $300 \mathrm{~m}$ of knotted cable lost during Leg 53 had probably slipped down to the bottom of the hole. All of the logging data are presented in Figures 2 and 3, along with the lithologic interpretation based on logs and core recovery column.

Eight years after Hole $418 \mathrm{~A}$ had been drilled, hole conditions proved to be very good, as shown by the three-arm-caliper curve. Caliper values higher than $11 \mathrm{in}$. are very rare (bit size $97 / 8$ in.). However, due to the mechanical properties of the formation and to the fact that no drilling mud was used to stabilize the hole, the borehole wall is locally rugose and slightly washed out. This does not seem to have affected the log response, however, with the exception of the lithodensity tool from 539 to 599 mbsf, where the response kicks too dramatically (density values down to $1.5 \mathrm{~g} / \mathrm{cm}^{3}$ ) to be caused only by lithologic changes. Most of these variations are also displayed, to a lesser degree, by the neutron and resistivity logs. The sonic log does not seem to be affected, suggesting that these excursions are due in part to poor contact between the lithodensity tool detector skid and the formation, thus causing the tool to "read" the borehole fluid.
No heave compensator was used on the logging cable. Sea conditions during logging were extremely calm and ship heave was less than $1 \mathrm{~m}$; thus, the effect on the logs is negligible.

Because all of the logging tools have been designed to minimize the effect of environmental conditions, corrections are required only when logging conditions greatly depart from the standards under which the tool has been calibrated (Schlumberger, 1972a). At Hole 418A the natural gamma-ray was corrected for hole size, and the neutron porosity for hole size and pressure. Also, from $464 \mathrm{mbsf}$ to the sediment/basement contact, a correction for standoff was applied to the neutron log in order to correct for neutron absorption by the borehole fluid. No correction was applied for neutron absorption by the pipe. Borehole corrections to the spherically focused resistivity and to the shallow laterolog were not required, because they are necessary only when the hole exceeds 12 in. in diameter. Corrections to the deep and medium resistivity logs also were not required, because the effect of the borehole fluid is relevant only when it is highly conductive (i.e., when $\mathrm{NaCl}$ exceeds 70,000 ppm). A summary of the applied corrections and their values is presented in Table 1.

Corrected logging data were first used to revise the basement lithostratigraphy defined during DSDP Legs 52 and 53. Core recovery in the logged interval averages $68 \%$, the highest ever obtained in oceanic basalts; differences between core- (Shipboard Scientific Parties, 1980b) and log-based unit boundaries are generally small, ranging from a few centimeters to about $6 \mathrm{~m}$ in Subunit 2B (Table 2). At Hole 418A the basement consists of pillow basalts, massive basalts, and basaltic breccia (Figs. 2 and $3)$. Each of these lithologies shows distinctive features on logs. Massive basalts correspond to very uniform log readings: low gamma-ray (3-8 GAPI units), high resistivity ( $>100 \mathrm{ohm}-\mathrm{m}$ ) and velocity (up to $6.2 \mathrm{~km} / \mathrm{s}$ ), and uniform bulk density (2.7$2.85 \mathrm{~g} / \mathrm{cm}^{3}$ ) and apparent porosity. In contrast, pillow basalts show a much higher degree of variability, with numerous deflections opposite altered zones and discontinuities between the pillows. The only basaltic breccia present at Hole 418A (Subunit $6 \mathrm{~A}$ ) is well delineated by the logs, and the top and bottom of this unit are clearly defined. Higher gamma-ray values (up to 29 GAPI units), lower resistivities (25-60 ohm-m), and low velocity $(3.5 \mathrm{~km} / \mathrm{s})$ distinguish this very heterogeneous lithology where density and porosity values reflect the presence of abundant alteration products. Generally, the highest variability in the log response has been observed in the interval from 389 to 514 mbsf (Unit 5-Subunit 6A), which is characterized by high gamma-ray values.

\section{CORE DATA}

To date, the physical properties of the rocks obtained from cores and logs have been handled as two separate categories of data, mainly because of the difficulty of comparing two measurements that are qualitatively and quantitatively different. It is important, however, to integrate these two data sets if we want to get a complete picture of the physical characteristics of the basement. Because we will critically review some of the laboratory measurements and use some of them in the processing of logging data, we present here a brief summary of laboratory results from Hole $418 \mathrm{~A}$.

Physical-property measurements at Hole 418A include compressional- and shear-wave velocities, bulk and grain densities, porosity, resistivity, and permeability (Hamano, 1980; Johnson, 1980a; Christensen et al., 1980; Shipboard Scientific Parties, $1980 \mathrm{~b})$. In most cases core data are not representative of the formation drilled because of the difficulty of simulating in-situ conditions in the laboratory and because core recovery and sample selection are biased. Also, the physical properties measured 




Figure 1. Location of DSDP Sites 417 and 418 (Shipboard Scientific Parties, 1980b). Bathymetry in meters.

on each core cylinder are controlled by the small-scale porosity present in the sample. In-situ fractures and voids cannot, by their very nature, be recovered by coring. On the other hand, representative samples of altered material were taken and the core scanned to determine their relative abundance so that a more accurate physical-property column could be reconstructed.

Figure 4 displays the bulk density as a function of porosity in the shipboard samples of Hole 418A (Shipboard Scientific Parties, 1980b). The plotted data do not include samples of the smectite vein fillings, which have a porosity higher than $15 \%$ and bulk density lower than $2.5 \mathrm{~g} / \mathrm{cm}^{3}$. Grain density of fresh samples ranges mostly from 2.9 to $3.0 \mathrm{~g} / \mathrm{cm}^{3}$ (Fig. 4A). As expected, altered samples have lower bulk-density values, due to the presence of low-density alteration products. The solid lines represent solutions for intrinsic densities of 2.9 to $3.0 \mathrm{~g} / \mathrm{cm}^{3}$, assuming a density of the formation fluid equal to that of seawater, $1.03 \mathrm{~g} / \mathrm{cm}^{3}$. Figures $4 \mathrm{~B}$ and $4 \mathrm{C}$ show a minimal difference between the average grain density of fresh massive and pillow basalts ( 2.97 and $2.95 \mathrm{~g} / \mathrm{cm}^{3}$, respectively). Therefore, because the compositional range is the same for the two lithologies, a value of $2.95 \mathrm{~g} / \mathrm{cm}^{3}$ is assumed to represent the intrinsic density of the formation. This value agrees with the value extrapolated by Hamano (1980) for Holes 418A and 417D and with the average shipboard grain density calculated for each sample (Shipboard Scientific Parties, 1980a, 1980b). This value also corresponds to the value estimated in 7.2-Ma crust drilled and logged at Hole 395A (Mathews et al., 1984).
The velocity-porosity relationship for shipboard samples was determined using a least-squares-fit method shown in Figure 5. As these measurements were made at atmospheric pressure, the fitted curve does not account for the actual in-situ effective pressure (which varies between 0.05 and $0.12 \mathrm{kbar}$ at the depths in question) that would tend to close cracks and voids and to increase the velocity. The value of velocity extrapolated at zero porosity is slightly lower than the $6.238 \mathrm{~km} / \mathrm{s}$ calculated by Christensen et al. (1980) at a confining pressure of $0.2 \mathrm{kbar}$. In any case, the linear relationship is a better solution to the core data than Wyllie et al.'s $(1956,1958)$ time-average equation that underestimates the porosity at low values $(0 \%-15 \%)$.

The limitations mentioned above also affect the determination of the density-velocity relationship of the shipboard data shown in Figure 6. It should be noted, however, that the differences between these two data sets are within the range of experimental uncertainty.

\section{PROCESSING AND INTERPRETATION OF THE LOGGING DATA}

From the point of view of logs the physical properties of a formation fall into two categories: properties that can be directly measured, such as sonic velocity and resistivity, and properties that are indirectly measured, such as bulk density and porosity. A correct determination of porosity is essential because most log responses depend primarily on porosity variations and on the way the pores are interconnected. 
C. BROGLIA, D. MOOS

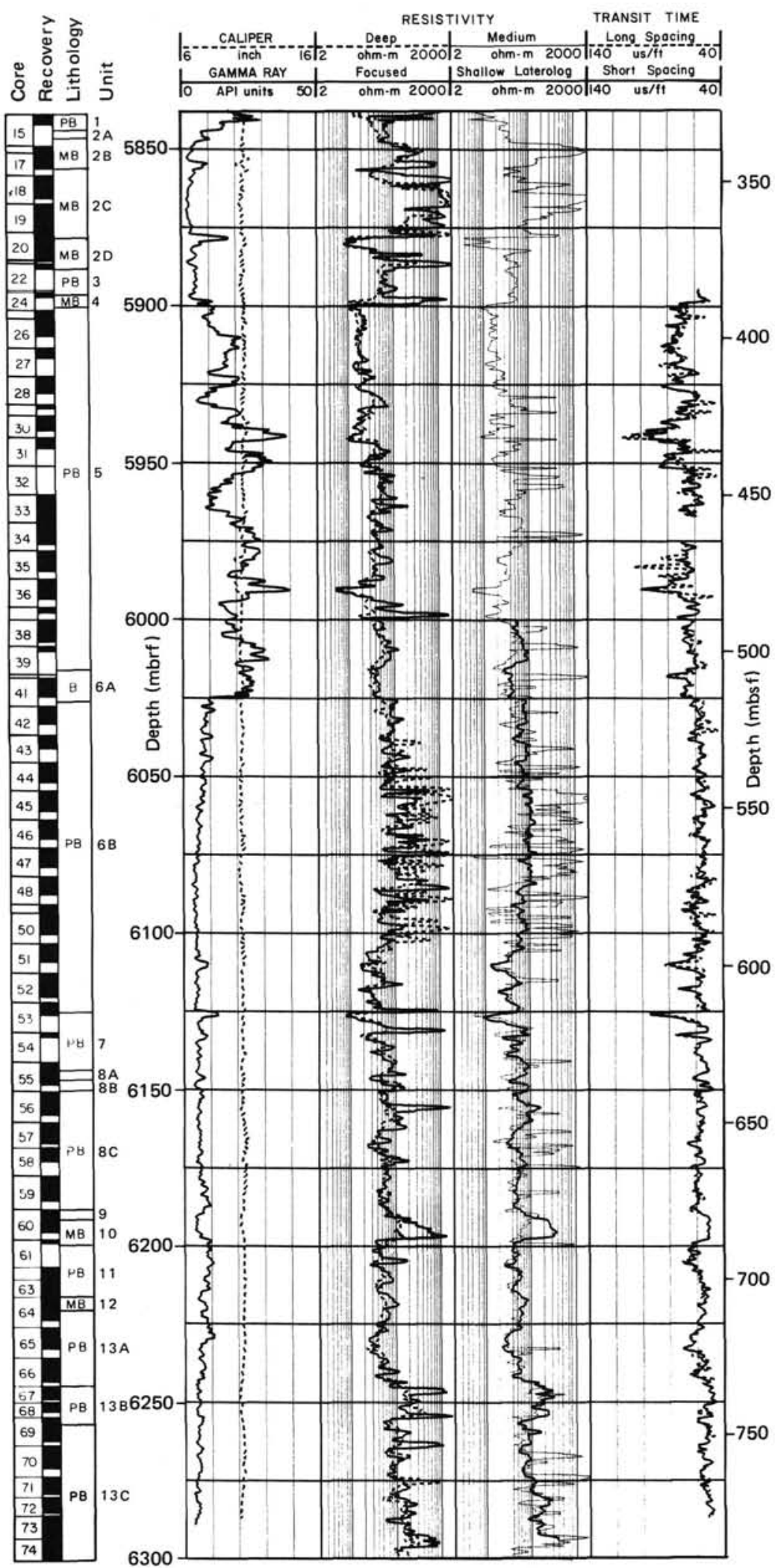

Figure 2. Core recovery, log-determined lithology, and logging data as a function of depth in Hole 418A. Sediment/basement contact at 324 mbsf. Gamma-ray curve corrected for borehole conditions (see text). Sonic data from 324 to $384 \mathrm{mbsf}$ were recomputed from the full waveforms (see Fig. 7), as the original data were affected by frequent cycle skipping. No data were recorded between 456 and 465 mbsf. Logging data are smoothed by using a 5 -point running average $(0.75-\mathrm{m}$ depth interval). $\mathrm{PB}=$ pillow basalt; $\mathrm{MB}=$ massive basalt; $\mathrm{B}=$ breccia. 


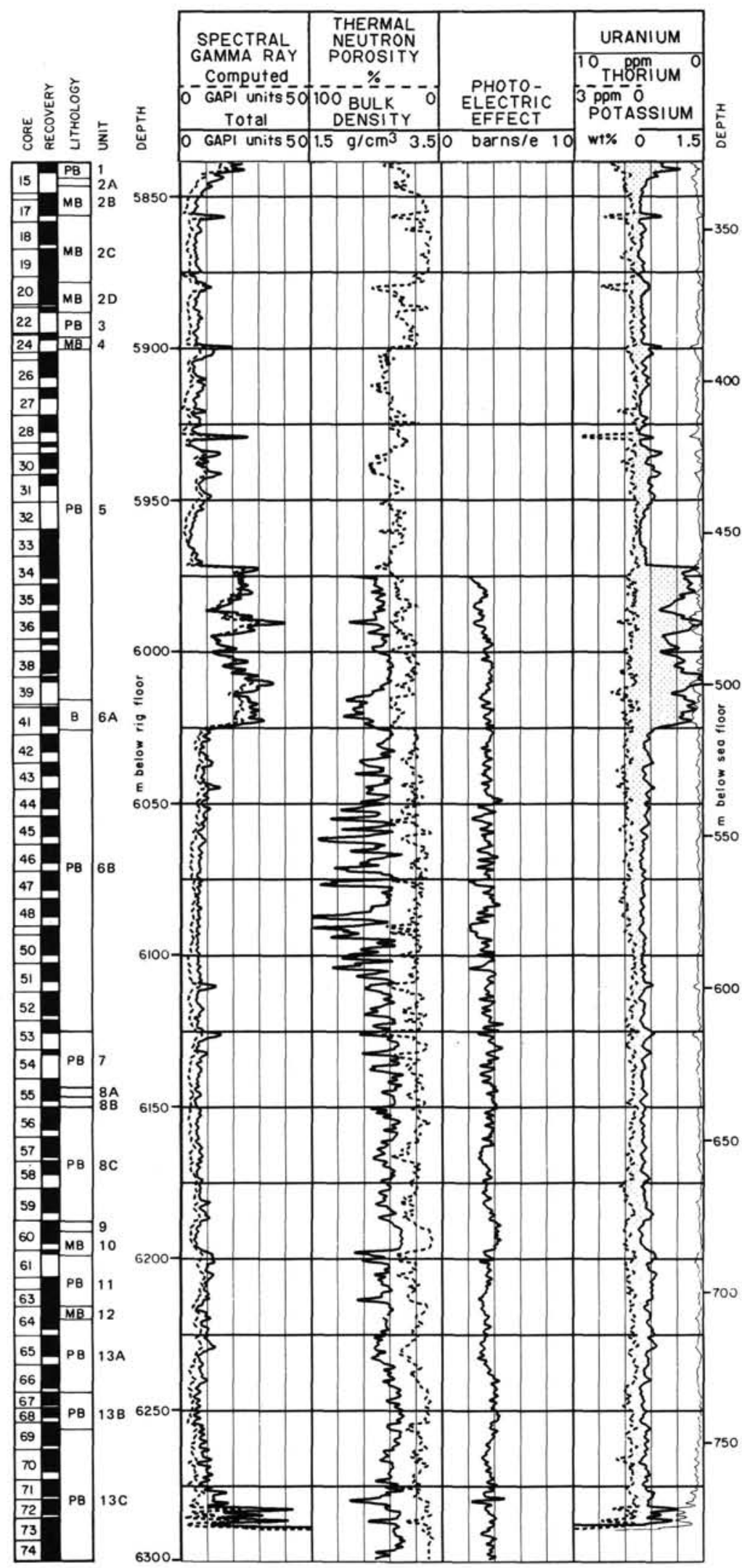

Figure 3. Core recovery, log-determined lithology, and logging data as a function of depth in Hole 418A. Spectral gamma-ray and neutron logs were run through the pipe from 324 to 464 mbsf. Neutron and density logs are corrected for borehole conditions (see text). Logging data are smoothed by using a 5-point running average $(0.75-\mathrm{m}$ depth interval). $\mathrm{PB}=$ pillow basalt; $\mathrm{MB}=$ massive basalt; $\mathrm{B}=$ breccia. 
Table 1. Summary of log corrections for borehole effects, Hole 418A.

\begin{tabular}{lccc}
\hline \multicolumn{1}{c}{ Log } & $\begin{array}{c}\text { Depth interval } \\
\text { (mbsf) }\end{array}$ & Correction & Range \\
\hline Gamma ray & $324-788$ & Hole size & +0.3 to 8.5 GAPI \\
Thermal neutron porosity & $324-464$ & a Standoff + pressure & $-4.3 \%$ to $-15.5 \%$ \\
& $464-788$ & Hole size + pressure & $-1.0 \%$ to $-13.0 \%$ \\
Bulk density & $464-788$ & bole size & \\
Resistivity & & No correction & \\
Spectral gamma ray & & No correction & \\
\hline
\end{tabular}

a No correction for the effect of the pipe.

b Correction performed aboard the ship during the recording.

Table 2. Basement units from logs and cores, Hole 418A.

\begin{tabular}{llcc}
\hline $\begin{array}{c}\text { Unit/ } \\
\text { Subunit }\end{array}$ & \multicolumn{1}{c}{ Lithology } & $\begin{array}{c}\text { Depth from logs } \\
\text { (mbsf) }\end{array}$ & $\begin{array}{c}\text { Depth from cores } \\
\text { (mbsf) }\end{array}$ \\
\hline 1 & Pillow basalt & $324.0-333.0$ & $324.0-329.6$ \\
2A & Massive basalt & $333.0-335.5$ & $329.6-331.7$ \\
2B & Massive basalt & $335.5-345.2$ & $331.7-339.0$ \\
2C & Massive basalt & $345.2-366.7$ & $339.0-363.1$ \\
2D & Massive basalt & $366.7-376.5$ & $363.1-376.6$ \\
3 & Pillow basalt & $376.5-385.0$ & $376.6-383.3$ \\
4 & Massive basalt & $385.0-388.0$ & $383.3-387.1$ \\
5 & Pillow basalt and breccia & $388.0-503.8$ & $387.1-498.5$ \\
6A & Breccia & $503.8-513.7$ & $498.5-510.5$ \\
6B & Pillow basalt & $513.7-614.0$ & $510.5-611.0$ \\
7 & Pillow basalt & $614.0-632.0$ & $611.0-629.2$ \\
8A & Pillow basalt & $632.0-636.0$ & $629.2-632.9$ \\
8B & Massive basalt & $636.0-639.0$ & $632.9-636.3$ \\
8C & Pillow basalt & $639.0-676.0$ & $636.3-671.8$ \\
9 & Massive basalt & $676.0-679.0$ & $671.8-676.5$ \\
10 & Massive basalt & $679.0-686.5$ & $676.5-686.0$ \\
11 & Pillow basalt & $686.5-703.5$ & $686.0-695.5$ \\
12 & Massive basalt & $703.5-707.5$ & $695.5-698.2$ \\
13A & Pillow basalt & $707.5-731.5$ & $698.2-$ \\
13B & Massive pillow basalt & $731.5-743.8$ & \\
13C & Pillow basalt & a 743.8-788.0 & -786.5 \\
\hline
\end{tabular}

a No $\log$ recorded below 788 mbsf.

It is well known that generally the thermal neutron porosity tool primarily responds to the concentration of hydrogen present in the formation either as free water or as bound water in clays and alteration products, but that it is sensitive also to the presence of such elements as silicon, chlorine, boron, and gadolinium, which are all strong neutron absorbers (Schlumberger, 1972a; Serra, 1984). Although the absorption properties of igneous rocks are not well understood, data obtained in holes drilled in oceanic crust show that neutron porosities in fresh massive basalts are as much as $10 \%$ higher than the true porosity (Lysne, in press; Salisbury et al., 1980), suggesting that mafic igneous rocks are stronger absorbers than sedimentary rocks. Standard corrections for the different types of matrix are applied to neutron logs recorded in lithologies such as sandstones, dolomites, and limestones (Schlumberger, 1985). In the case of igneous rocks, whenever the tool was not properly calibrated (Mathews et al., 1985), the only way to calibrate logs is against core data.

In order to calibrate neutron log porosity data against core porosity it is necessary to choose an interval where logs "see" the same type of porosity measured on the cores. The component of porosity measured on cores is a small-scale porosity, consisting of isolated vesicles and interstitial pores. At Hole 418A this porosity ranges from $2 \%$ in fresh massive basalts to $12 \%$ in altered basalts (3\% to $10 \%$ in nearby Hole $417 \mathrm{D})$. This porosity is poorly interconnected and exhibits a low permeability (Hamano, 1980; Johnson, 1980b). In addition to this smallscale porosity, logs respond to a larger scale porosity in the form of fractures, voids between pillows, and breccia zones. This po- rosity is better interconnected and is responsible for the high permeability of the shallow oceanic crust (Becker, 1985).

At Hole $418 \mathrm{~A}$ the calibration of neutron-density data was performed in the massive basalt units logged open-hole, which were assumed to be fresh and free of fractures. Unit 10 in particular exhibits very low gamma-ray values and uniform log readings. Corrections of $-6 \%$ and $+0.04 \mathrm{~g} / \mathrm{cm}^{3}$ were applied to the neutron and density logs, respectively, as shown by the arrows in Figure 7, a display of the data before correction.

A comparison of physical properties from logs and cores is presented in Figure 8, along with the natural gamma-ray curve. In the interval from 324 to $384 \mathrm{mbsf}$, velocities were recomputed from Schlumberger sonic waveforms using a technique described by Moos (this volume). No data were recorded from 456 and 464.5 mbsf owing to a lack of overlap between the two logging runs. As expected, velocities and bulk densities are lower than laboratory-determined values, except within the massive basalt units. Most of this difference is due to the large-scale porosity that is not sampled by the drill bit but that reduces in-situ formation velocity and density. Logging data fall between the values for smectite fillings and those for fresh to moderately altered basalts, suggesting that smectite, in filling some of the voids and fractures, also decreases log values.

The compressional velocity ranges from 3.5 to $6.3 \mathrm{~km} / \mathrm{s}$, with an average value of $5.07 \mathrm{~km} / \mathrm{s}(4.78$ and $5.38 \mathrm{~km} / \mathrm{s}$ in the upper (Units 1-Subunit 6A) and lower (Subunits 6B-13C) intervals, respectively). This value is consistent with the value of 4.8 $\mathrm{km} / \mathrm{s}$ at Hole 417D (Salisbury et al., 1980b), but it is much higher than the $3.6 \mathrm{~km} / \mathrm{s}$ of Layer 2A drilled in 13-Ma-old crust on the Mid-Atlantic Ridge at Hole 396B (Kirkpatrick, 1979a, $1979 \mathrm{~b})$. These results suggest that velocity increases with age in the upper part of the crust, as also indicated by regional seismic-refraction results (Houtz and Ewing, 1976).

Most of the density values fall between 2.5 and $2.95 \mathrm{~g} / \mathrm{cm}^{3}$, with an average of $2.58 \mathrm{~g} / \mathrm{cm}^{3}\left(2.44\right.$ and $2.72 \mathrm{~g} / \mathrm{cm}^{3}$ in the upper (bottom part of Unit 5-Subunit 6A) and lower (Subunits 6B13C) intervals, respectively). The higher value at Hole 417D $\left(2.71 \mathrm{~g} / \mathrm{cm}^{3}\right.$; Salisbury et al., 1980b) was calculated in the topmost $100 \mathrm{~m}$ of basement, consisting mainly of fresh to slightly altered pillow basalts.

Calibrated neutron porosities are much higher than those from core data except in the massive basalt units. This difference is greatest in the $388-514$ mbsf interval, which is also characterized by high (up to 50 GAPI units) gamma-ray readings; a correction for the volume of smectite (described in the following) is thus necessary to get the total porosity.

The gamma-ray response in oceanic basalts is very low, with values usually lower than 15 GAPI units. In sedimentary formations the gamma-ray log generally reflects the clay-mineral content of the rock because radioactive elements tend to concentrate in clays. In basaltic rocks high gamma-ray readings, such as observed in the upper part of Hole 418A (Fig. 9), are mainly related to the presence of potassium-rich minerals that form by the alteration of basalts in the presence of seawater. Analyses of 

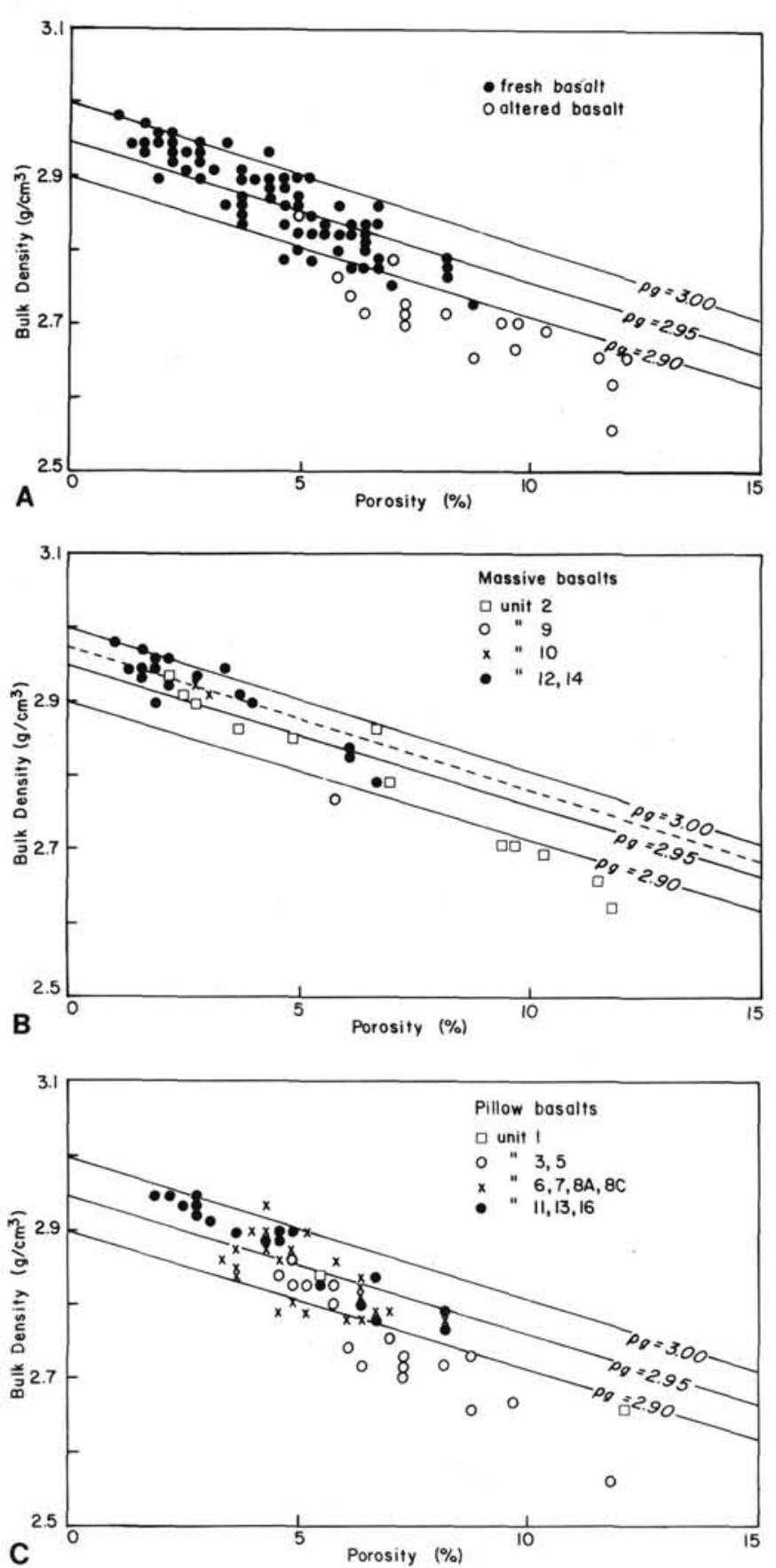

Figure 4. Bulk density as a function of porosity from shipboard measurements on samples from Hole 418A (Shipboard Scientific Parties, 1980a). Smectite fillings are not included. Distinction shown between fresh and altered basalts (A) and between massive and pillow basalt units $(\mathrm{B}, \mathrm{C})$. Solid lines represent the density-porosity relationship as a function of grain density, assuming a fluid density of $1.03 \mathrm{~g} / \mathrm{cm}^{3}$ and ignoring the possible presence of a third phase (smectite or other alteration materials).

recovered cores indicated that the highest values of potassium (up to $9 \%$ by weight) have been found in highly altered basalts and fragments of basaltic breccia; the lowest values $(0.01 \%$ by weight) are from the centers of the larger pillows and in the massive ophitic units (Storzer and Solo, 1980). Also, an enrichment of the bulk uranium content occurs with the increase of potassium (Storzer and Solo, 1980; also see the uranium curve between 464 and 514 mbsf in Fig. 3). At Hole 418A the most abundant alteration products are clay minerals of the smectite group (Mevel, 1980; Pritchard, 1980; Pertsev and Rusinov, 1980; Rusinov et al., 1980). In general, the smectite clays do not contain potassium. The bright green smectites associated with the basalts of Sites 417 and 418 , however, are rich in potassium (Pritchard, 1980; Humphris et al., 1980), which was extracted from seawater during the alteration process. They occur in veins and fractures, as vesicle linings, and as alteration products of mafic minerals, mostly olivine (Scarfe, 1980).

The alteration profile obtained from logs, core samples (Shipboard Scientific Parties, 1980b; Emmermann and Puchelt, 1980; Flower et al., 1980; Humphris et al., 1980), and barrel sheets is shown in Figure 9. A good correlation can be observed between $\log$ and core data, both of which exhibit the highest values in the 388-514 mbsf interval. The alteration index obtained by comparing the state of alteration of the cores as derived from barrel sheets (Shipboard Scientific Parties, 1980b) to the core recovery is also in good agreement. Assuming that no radioactive mineral other than smectite is present in the logged interval, its volume may be estimated from the gamma-ray curve

$$
V_{\text {sme }}=\left(G R-G R_{\min }\right) /\left(G R_{\max }-G R_{\min }\right),
$$

where $V_{\text {sme }}$ is the volumetric percentage of smectite and GR is the log reading. $\mathrm{GR}_{\min }$ and $\mathrm{GR}_{\max }$ correspond to values in fresh (3 GAPI units) and highly altered (90 GAPI units) basalt; the latter value has not been derived directly from the log readings but has been assumed in order to obtain computed values ranging from $10 \%$ to $45 \%$ in the most altered interval (388-514 mbsf), which are compatible with those estimated from the cores by Shipboard Scientific Parties (1980b).

If one considers the basaltic rock as a three-component system (matrix, smectite, and water-filled porosity) the total porosity of the formation can be computed as the average of the porosities calculated from the neutron and the density logs, each corrected for smectite content:

$$
\begin{gathered}
\phi_{\mathrm{nc}}=\phi_{\mathrm{n}}-\phi_{\mathrm{nsme}} \mathrm{V}_{\mathrm{sme}} \\
\phi_{\mathrm{dc}}=\phi_{\mathrm{d}}-\phi_{\mathrm{dsme}} \mathrm{V}_{\mathrm{sme}},
\end{gathered}
$$

where

$$
\begin{gathered}
\phi_{\mathrm{d}}=\left(\rho_{\mathrm{ma}}-\rho_{\mathrm{b}}\right) /\left(\rho_{\mathrm{ma}}-\rho_{\mathrm{f}}\right) \\
\phi_{\mathrm{dsme}}=\left(\rho_{\mathrm{ma}}-\rho_{\mathrm{sme}}\right) /\left(\rho_{\mathrm{ma}}-\rho_{\mathrm{f}}\right),
\end{gathered}
$$

and

$$
\begin{aligned}
\phi_{\mathrm{nc}} & =\text { corrected neutron porosity } \\
\phi_{\mathrm{dc}} & =\text { corrected density porosity } \\
\phi_{\mathrm{n}} & =\text { apparent neutron porosity (calibrated) } \\
\phi_{\mathrm{d}} & =\text { apparent density porosity (calibrated) } \\
\phi_{\mathrm{dsme}} & =\text { density porosity for smectite } \\
\phi_{\mathrm{nsme}} & =\text { neutron porosity for smectite } \\
\mathrm{V}_{\mathrm{sme}} & =\text { volumetric percentage of smectite } \\
\rho_{\mathrm{b}} & =\text { bulk density } \\
\rho_{\mathrm{ma}} & =\text { grain density } \\
\rho_{\mathrm{f}} & =\text { fluid density } \\
\rho_{\mathrm{sme}} & =\text { smectite bulk density }
\end{aligned}
$$

assuming $\phi_{\text {nsme }}=44 \%$ (Edmunson and Raymer, 1979), $\rho_{\mathrm{ma}}=$ $2.95 \mathrm{~g} / \mathrm{cm}^{3}, \rho_{\text {sme }}=2.45 \mathrm{~g} / \mathrm{cm}^{3}$ (Shipboard Scientific Parties, $1980 \mathrm{~b})$, and $\rho_{\mathrm{f}}=1.03 \mathrm{~g} / \mathrm{cm}^{3}$.

The corrected values of total porosity allow us to determine the velocity-porosity relationship at the effective in-situ pressure. Because smectite decreases the formation velocity (average smectite velocity from cores is $4.17 \mathrm{~km} / \mathrm{s}$, from Shipboard Scientific Parties, 1980b), data plotted in Figure 10 are from the 654-775 mbsf interval, where alteration is low and velocity primarily depends on porosity variations and the way the porosity 


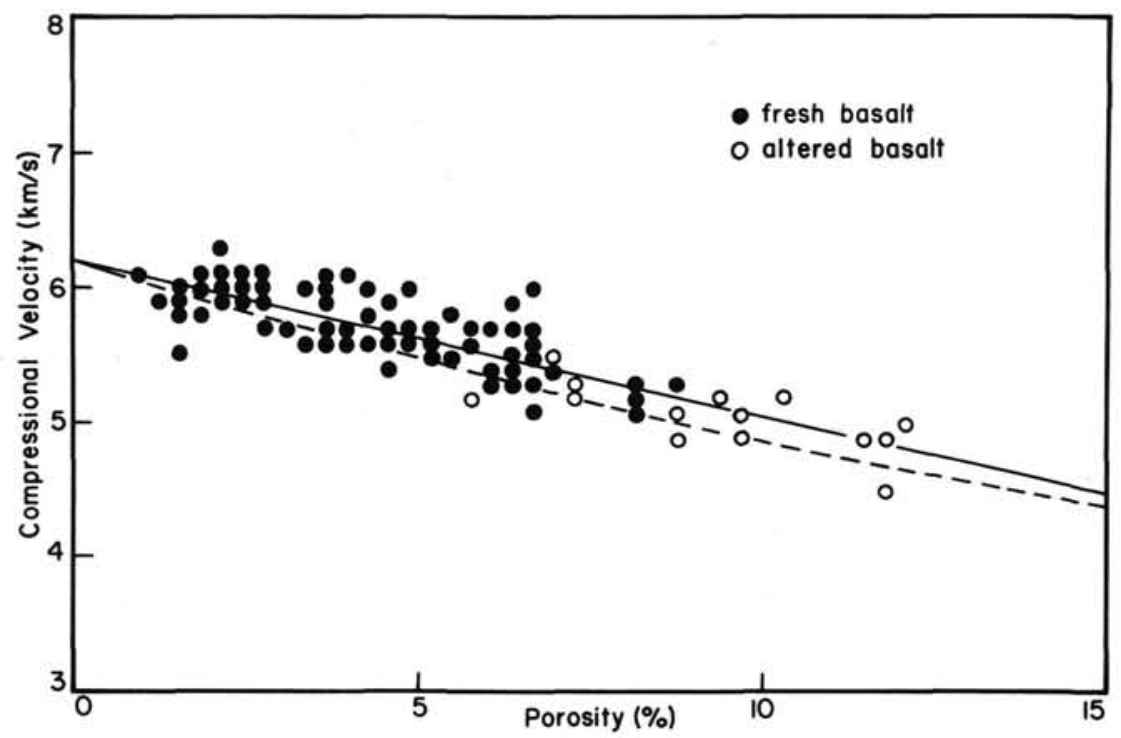

Figure 5. Compressional-wave velocity vs. porosity measured at atmospheric pressure on shipboard samples from Hole 418A (Shipboard Scientific Parties, 1980b). Smectite fillings are not included. The solid line is the linear least-squares solution to the data $\left(\mathrm{V}_{p}=\mathrm{b}+m \phi\right.$; $\mathrm{b}=6.207, m=-0.12$, correlation coefficient $=0.86$ ); the dashed line is calculated from the time-average equation (Wyllie et al., 1956, 1958).

is interconnected. Superimposed on the data are

1. The best linear fit to the logging data (this study),

$$
\mathrm{V}_{p}=6.224-0.065 \phi(\phi \text { expressed in \%). }
$$

2. The best linear fit to the core data from Holes $418 \mathrm{~A}$ and 417D, measured by Christensen et al. (1980) at $0.2 \mathrm{kbar}$,

$$
\mathrm{V}_{p}=6.238-0.22 \phi(\phi \text { expressed in } \%) \text {. }
$$

3. The nonlinear velocity-porosity relation derived by Hyndman et al. (1984) from the velocity measurements performed by Christensen and Salisbury (1975) at 0.5 kbar on DSDP basalts,

$$
\mathrm{V}_{p}=6.44-9.61 \phi^{2}(\phi \text { expressed as a fraction }) .
$$

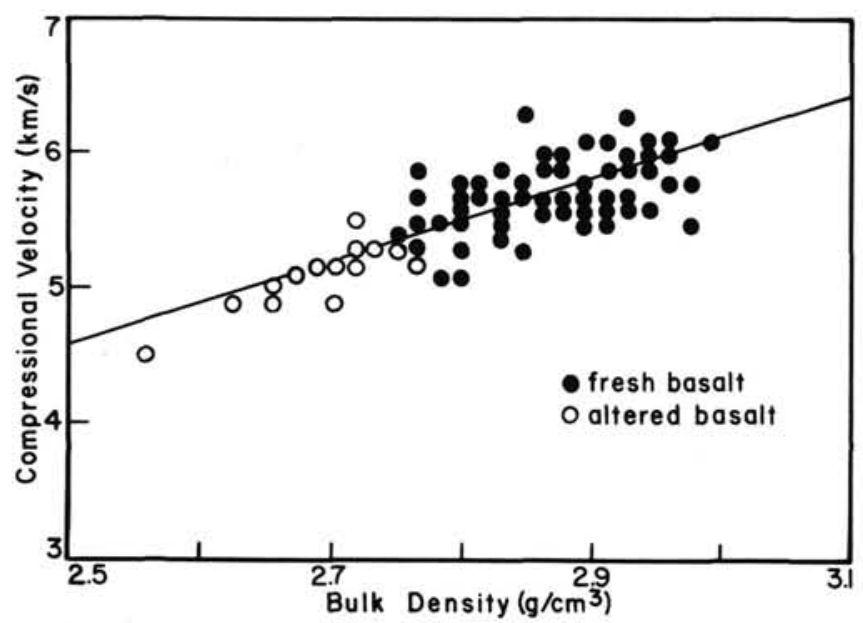

Figure 6. Compressional-wave velocity vs. bulk density measured at atmospheric pressure on shipboard samples from Hole 418A (Shipboard Scientific Parties, 1980b). Smectite fillings are not included. The leastsquare solution to the data is shown as well. $\mathrm{V}_{p}=\mathrm{b}+m \phi ; \mathrm{b}=$ $-3.17, m=3.10$, correlation coefficient $=0.81$.
4. The time-average equation proposed by Wyllie et al. (1956, 1958),

$$
1 / V_{p}=\phi / V_{f}+(1-\phi) / V_{m a}(\phi \text { expressed as a fraction), }
$$

where $V_{f}$ and $V_{m a}$ are the fluid $(1.61 \mathrm{~km} / \mathrm{s})$ and matrix $(6.224$ $\mathrm{km} / \mathrm{s}$ ) velocities, respectively. Figure 10 shows that core measurements, even if performed at simulated in-situ pressure (Christen-

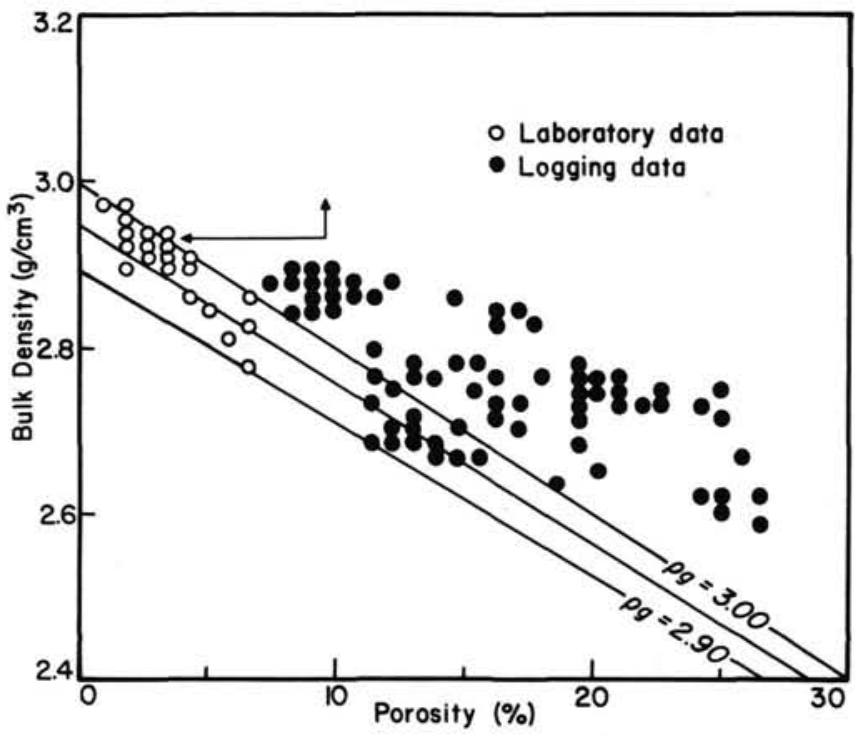

Figure 7. Bulk density vs. porosity from logs (solid circles, before calibration), and from shipboard samples (open circles, Shipboard Scientific Parties, 1980b). Calibration was performed in massive basalt Subunit $8 \mathrm{~B}$ and Units 9,10 , and 12 against core data from Units $2,9,10$, 12 , and 14. Arrows represent bulk-density and neutron porosity corrections of $+0.04 \mathrm{~g} / \mathrm{cm}^{3}$ and $-6 \%$, respectively. Solid lines represent solutions at extrapolated grain densities of $2.9,2.95$, and $3.0 \mathrm{~g} / \mathrm{cm}^{3}$. 


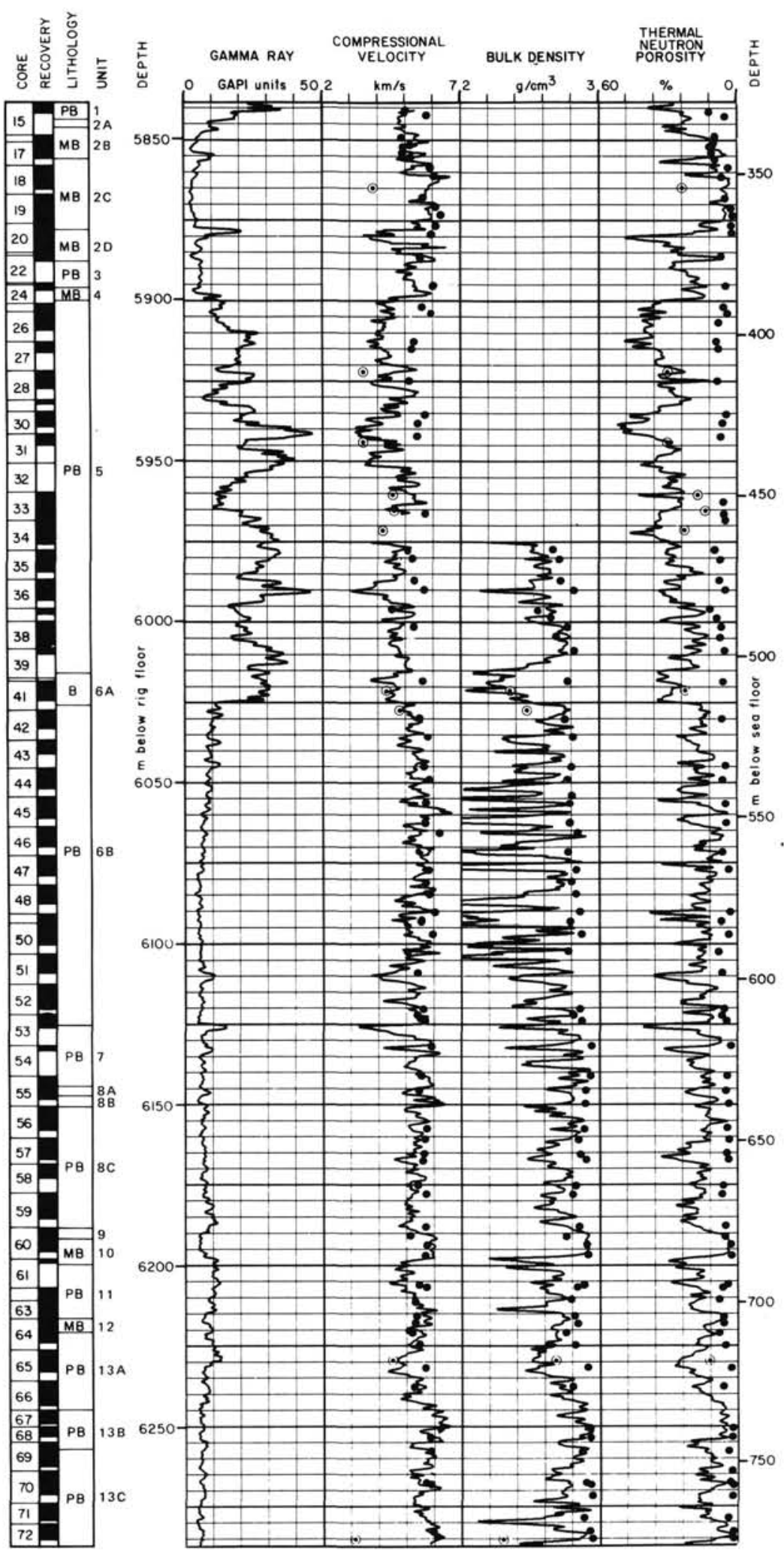

Figure 8. Comparison of compressional-wave velocity, calibrated bulk density, and neutron porosity from logs against laboratory data (Shipboard Scientific Parties, 1980b), as a function of depth. Open circles represent smectite fillings, solid circles basalt samples. Logs match core data in massive basalt Units 2, 10, and 12 and in massive pillow basalt Subunit 13B, indicating a low degree of fracturing. Discrepancies between log and core data in the rest of the hole suggest that the formation is locally highly altered (high gamma-ray) and fractured. $\mathrm{PB}=$ pillow basalt; $\mathrm{MB}=$ massive basalt; $\mathrm{B}=$ breccia. 


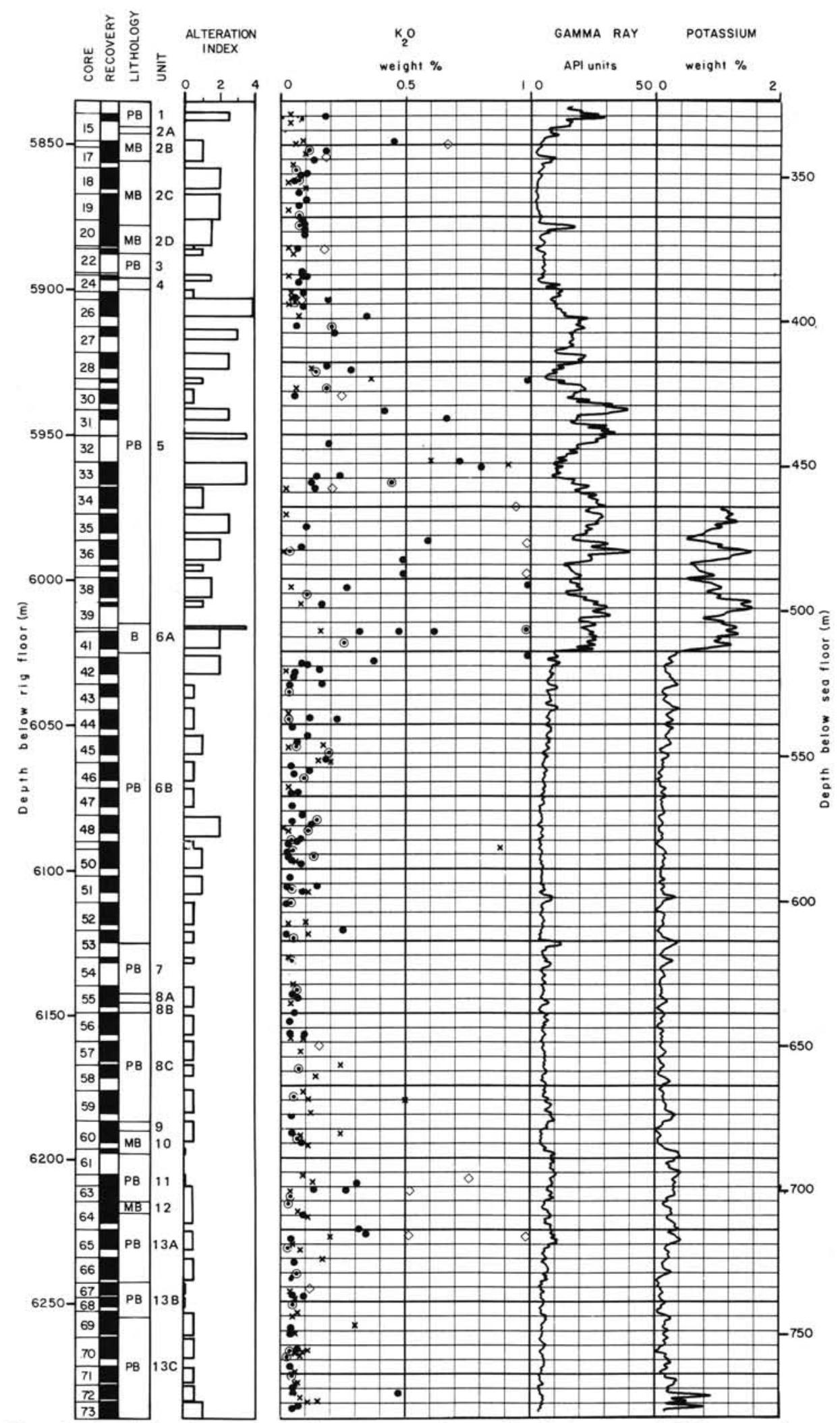

Figure 9. Correlation between natural gamma-ray and potassium log curves and $\mathrm{K}_{2} \mathrm{O}$ content from core samples (crosses, Shipboard Scientific Parties, 1980b; open circles, Emmermann and Puchelt, 1980; solid circles, Flower et al., 1980; diamonds, Humphris et al., 1980). Log and core data show that alteration is very high in the $388-514$ mbsf interval, also suggesting that K-rich smectite is the dominant alteration product. The alteration index was obtained by comparing the state of alteration of the cores as derived from barrel sheets of Site 418 (Shipboard Scientific Parties, 1980b) to the core recovery. $\mathrm{PB}=$ pillow basalt; $\mathrm{MB}=$ massive basalt; $\mathrm{B}=$ breccia. 


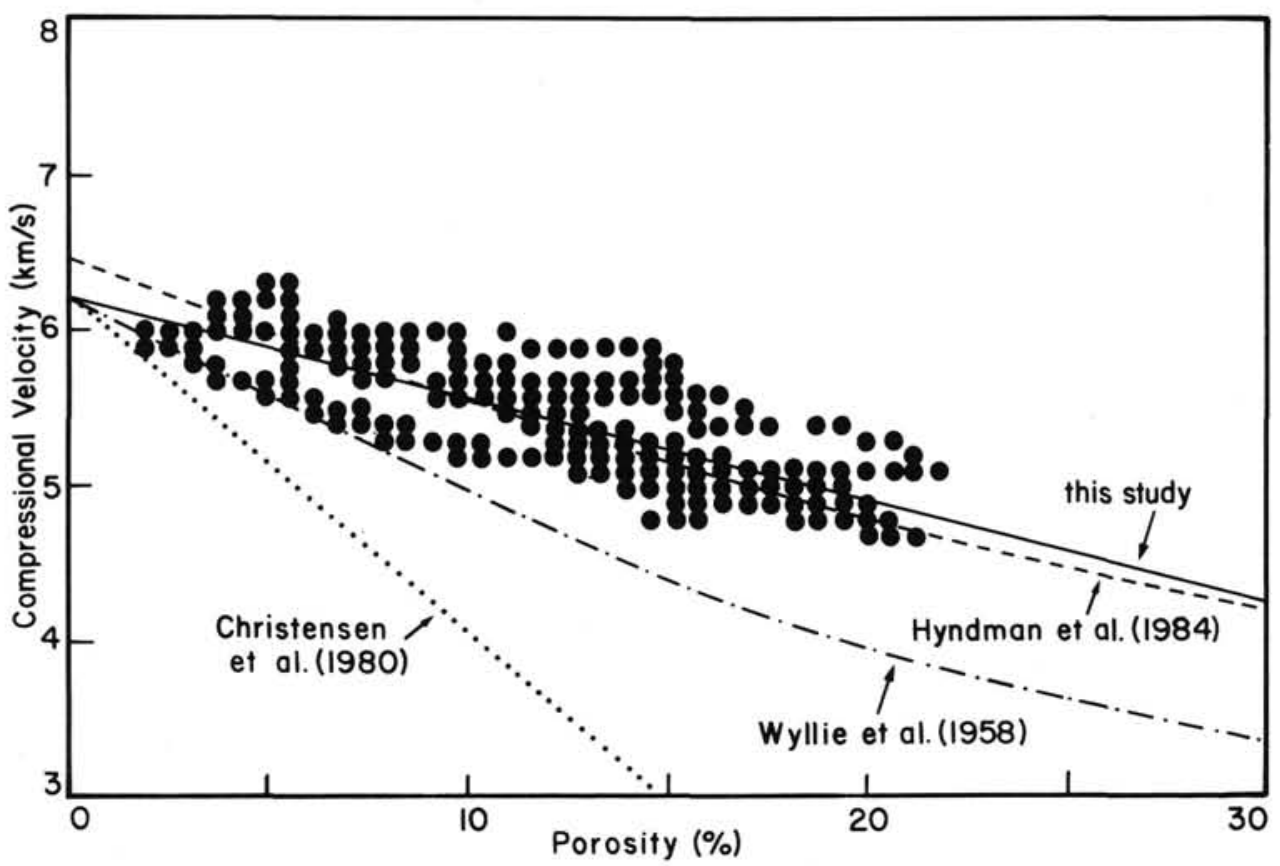

Figure 10. Compressional-wave velocity vs. porosity from logs of Hole $418 \mathrm{~A}$. Porosity is from the densityneutron combination, after calibration. The solid line represents the linear solution to the data from logs (this study); $\mathrm{V}_{p}=\mathrm{b}+m \phi, \mathrm{b}=6.224, m=-0.065$, correlation coefficient $=0.82$. Also shown are the linear solution to core data from Sites 417 and 418 (Christensen et al., 1980), the nonlinear relationship derived by Hyndman et al. (1984), and the time-average equation (Wyllie et al., 1956, 1958).

sen et al., 1980), are not representative of the real physical properties of the formation at Hole $418 \mathrm{~A}$. The intrinsic velocities from logs and cores are very close, but the steeper slope of the latter indicates that porosities are much too low (i.e., that porosities were underestimated). This seems to be confirmed by Figure 11 as well, showing that core velocity data are in the same range displayed by logs. As already pointed out in the case of core samples (Fig. 5), Wyllie et al.'s $(1956,1958)$ equation also underestimates the porosity for a particular value of velocity. Instead, the nonlinear solution proposed by Hyndman et al. (1984) appears to be a better fit to the logging data, even though in the range above $10 \%$ it gives porosity values that are up to $2 \%$ lower than those from the neutron-density combination.

Figure 10 confirms once again that one solution alone does not properly characterize the in-situ velocity-porosity relationship. In fact, each porosity corresponds to a pretty wide range of velocity values that might depend on the size of voids and fractures, as well as on their geometry. Toksöz et al. (1976) determined that in sedimentary rocks, flat (thin) cracks decrease the formation velocity significantly, whereas only a small decrease is produced by spherical or angular voids and fractures (see also Salisbury et al., 1985).

\section{DISCUSSION}

Oceanic basalts can be considered simply as an aggregate of three major components: basalt matrix, water-filled porosity, and alteration products. Properties are controlled by the amount and distribution of these components and by primary structure.

Laboratory results detail the relationships between porosity, density, velocity, and resistivity. The properties of the grains themselves vary considerably less than those of the core plugs, and thus can be considered to be quite similar regardless of the source of the material (e.g., Schreiber and Fox, 1976). For most basalts grain density is between 2.95 and $3.05 \mathrm{~g} / \mathrm{cm}^{3}$, extrapolated zero-porosity velocities are about $6.3 \mathrm{~km} / \mathrm{s}$, and grain re- sistivities are several orders of magnitude larger than pore-fluid resistivities and thus can be considered infinite. Velocity and bulk density decrease with increasing porosity.

The porosity-velocity relationship shown in Figure $5\left(\mathrm{~V}_{p}=\right.$ $6.207-0.12 \phi)$ adequately fits the core data from this hole. A best linear fit to the density-porosity data yields a matrix density of $2.95 \mathrm{~g} / \mathrm{cm}^{3}$ for pillows and $2.97 \mathrm{~g} / \mathrm{cm}^{3}$ for massive flows. The linear relationship between density and velocity for these cores is a consequence of the above relationships. For these cores $\mathrm{V}_{p}=3.10 \rho_{\mathrm{b}}-3.17$.

Similar results have been obtained from the logging data at Hole $418 \mathrm{~A}$. In fresh massive basalts porosity and density are linearly related, with an extrapolated grain density of 2.9 to 3.0 $\mathrm{g} / \mathrm{cm}^{3}$ (Fig. 7). The range represents the scatter in the data and is perhaps due to variations in the amount of alteration material not reflected in the gamma-ray log. Based on studies at Sites 417 and 418 by Mevel (1980) and Pritchard (1980), these include calcite, chlorite, and low-potassium feldspars and clays. Compressional-wave velocity and porosity are also linearly related by the relationship $\mathrm{V}_{p}=6.224-0.065 \phi$ (Fig. 10). Although calculated from the logs, this relationship is remarkably similar to Hyndman et al.'s (1984) best-fit equation for DSDP core data. Nonetheless, it suggests that in-situ velocity is slightly less sensitive to porosity than laboratory data are. The density-velocity relationship for the logs is displayed in Figure 11. The leastsquares fit to the log data is $V_{p}=2.914 \rho_{\mathrm{b}}-2.517$. Again, the in-situ velocity appears to be slightly less sensitive to density than the laboratory data are. This is not surprising, in light of the difference in velocity sensitivity, as density is controlled here almost entirely by porosity. However, the difference in sensitivity of velocity to porosity for cores and logs deserves further comment. This disparity implies that not all of the in-situ porosity is effective in decreasing velocity. Although this may be due in part to systematic overestimation of the porosity of the altered materials, a more reasonable explanation is that the sen- 


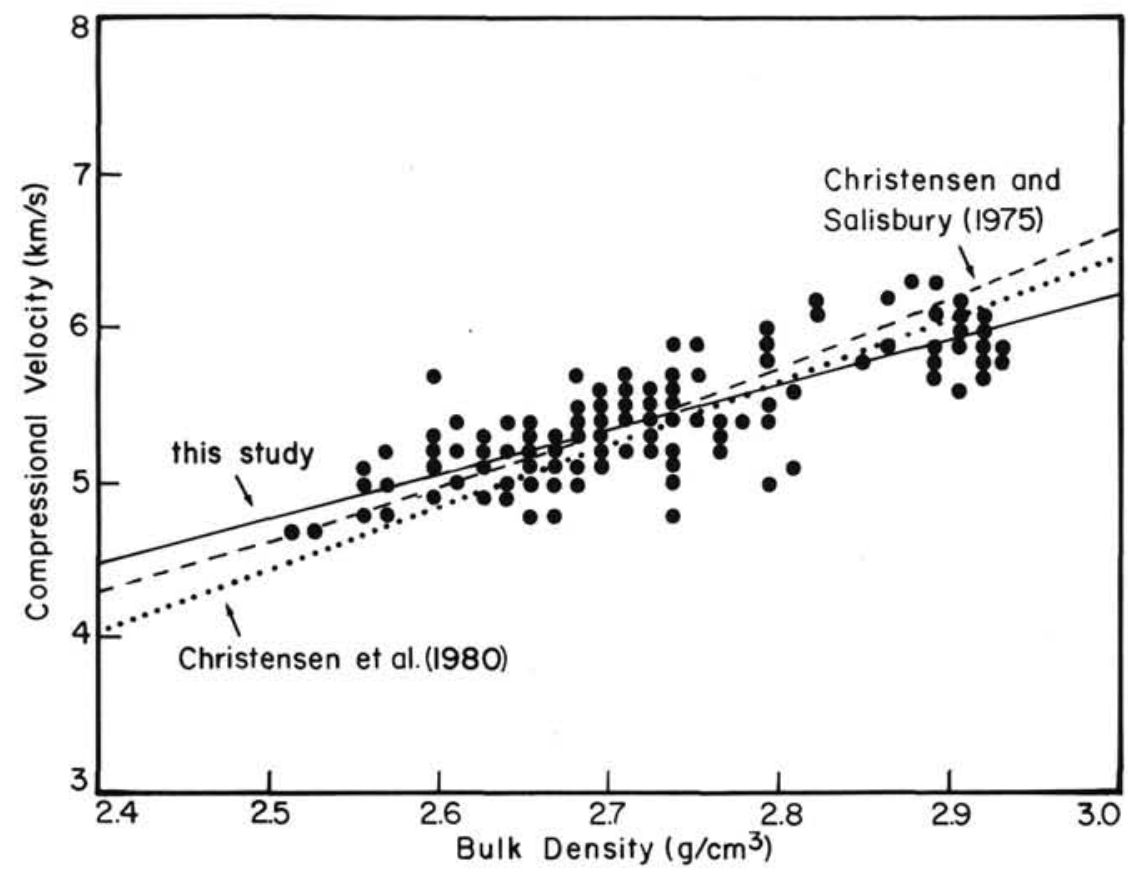

Figure 11. Velocity/density relationship from logs of Hole 418A. The solid line represents the linear solution to the data from logs (this study): $\mathrm{V}_{p}=m_{\rho}+\mathrm{b}, \mathrm{b}=-2.517, m=2.914$, correlation coefficient $=0.81$. The least-squares fit to core data from Sites 417 and 418 (Christensen et al., 1980), and the nonlinear solution to data from DSDP basalts (Christensen and Salisbury, 1975), are shown as well.

sitivity of the various logs to the pore space depends on the type of porosity involved.

Figure 12 is a cross-plot of density-normalized neutron and sonic porosities, $\mathrm{M}$ and $\mathrm{N}$, defined by

$$
\begin{gathered}
\mathrm{M}=0.01\left(\mathrm{Dt}_{\mathrm{f}}-\mathrm{Dt}\right) /\left(\rho_{\mathrm{b}}-\rho_{\mathrm{f}}\right), \\
\mathrm{N}=\left(\phi_{\mathrm{nf}}-\phi_{\mathrm{n}}\right) /\left(\rho_{\mathrm{b}}-\rho_{\mathrm{f}}\right),
\end{gathered}
$$

where $\mathrm{Dt}_{\mathrm{f}}$ and $\mathrm{Dt}$ are the fluid and measured sonic slownesses, $\phi_{\mathrm{n}}$ and $\phi_{\mathrm{nf}}$ are the calibrated neutron and the fluid porosities, and $\rho_{\mathrm{b}}$ and $\rho_{\mathrm{f}}$ are the calibrated $\log$ and fluid densities. Data from the 539-599 mbsf interval, where density was affected by bad hole conditions, are not plotted. The large variation in $\mathbf{M}$ demonstrates that whereas neutron and density readings vary proportionally with total porosity, the sonic data are less affected, and thus, that some part of the in-situ porosity is not "seen" by the sonic log. This was also observed by Salisbury et al. (1980a) in DSDP Hole 417D.

Thus, the effect of the fractures and voids is reflected by density and porosity measurements but is not observed as strongly in sonic data. This result is often used in traditional log analysis of sedimentary rocks to determine the "fracture porosity" of the formation, as standard practice suggests that sonic velocities are not sensitive to fractures (Schlumberger, 1972b). Similarly, this difference could be used in oceanic basalts to separate the in-situ porosity into "primary" (matrix) and "secondary" (fracture and void) porosity. In this case, however, the effect of voids and fractures on sonic velocity probably depends on their size relative to the sonic wavelength. The range of frequencies used in sonic logging is 5 to $20 \mathrm{kHz}$, and its wavelength for velocities between 5 and $6 \mathrm{~km} / \mathrm{s}$ is 1.2 to $0.25 \mathrm{~m}$. This is similar to the size of basalt pillows (Shipboard Scientific Parties, 1980b). These features tend to scatter the sonic energy rather than to decrease the effective sonic velocity (see Moos, this volume, for a more detailed discussion). Similarly, although Moos and Zoback (1983) observed large changes in velocities within fractured intervals in granites, they attributed this largely to alteration associated with the fractures rather than to the effect of the fractures themselves.

Figure 13 illustrates the fact that sonic velocities are nonetheless somewhat decreased by fractures and voids. For example, the average value of sonic-computed porosity in the lower, relatively fresh basalts is $11.3 \%$, only $1.8 \%$ lower than porosity determined from the density-neutron combination. The average fracture porosity in this interval is about $5.4 \%$ (Table 3 ); thus, the sonic tool is sensitive to most of this fracturing. In the interval from 324 to $464 \mathrm{mbsf}$, where the neutron log run through the pipe overestimated the porosity, sonic measurements provide a better estimate. Correction of the sonic porosities for alteration is accomplished in the same manner as corrections to the neutron and density porosities.

Figure 14 and Table 3 present a summary of the physical properties of the upper part of the basement at Hole 418A. The total porosity was calculated from the density-neutron combination, corrected for the smectite content. Based on the assumption that massive basalts are fracture-free, a velocity-porosity relationship obtained in these units was used to estimate the primary porosity. This assumption does not take into account the larger scale primary porosity present in the pillow units, but the good match between logs and cores in the massive units and subunits $(2,8 \mathrm{~B}, 9,10$, and 12$)$ and the slightly higher value of porosity computed in pillow basalts suggest that this curve represents a good estimate of primary porosity. Based on smectite content and variations in porosity and velocity, the basement can be subdivided into three zones. The upper one, zone 1 , consists mainly of fresh or slightly altered massive basalts (Units 14) and is characterized by high mean velocity $(5.07 \mathrm{~km} / \mathrm{s})$, low total porosity $(12.6 \%)$, and a fracture porosity of $4.6 \%$. The intermediate zone 2 (Unit 5-Subunit 6A) is composed of highly altered pillow basalts and breccia and has a mean velocity of $4.51 \mathrm{~km} / \mathrm{s}$ and higher total $(19.7 \%)$ and fracture $(6.2 \%)$ porosities. The lower zone 3 (Subunits $6 \mathrm{~B}-13 \mathrm{C}$ ) is formed mainly of pillow basalts and displays a mean velocity of $5.38 \mathrm{~km} / \mathrm{s}$, a total poros- 


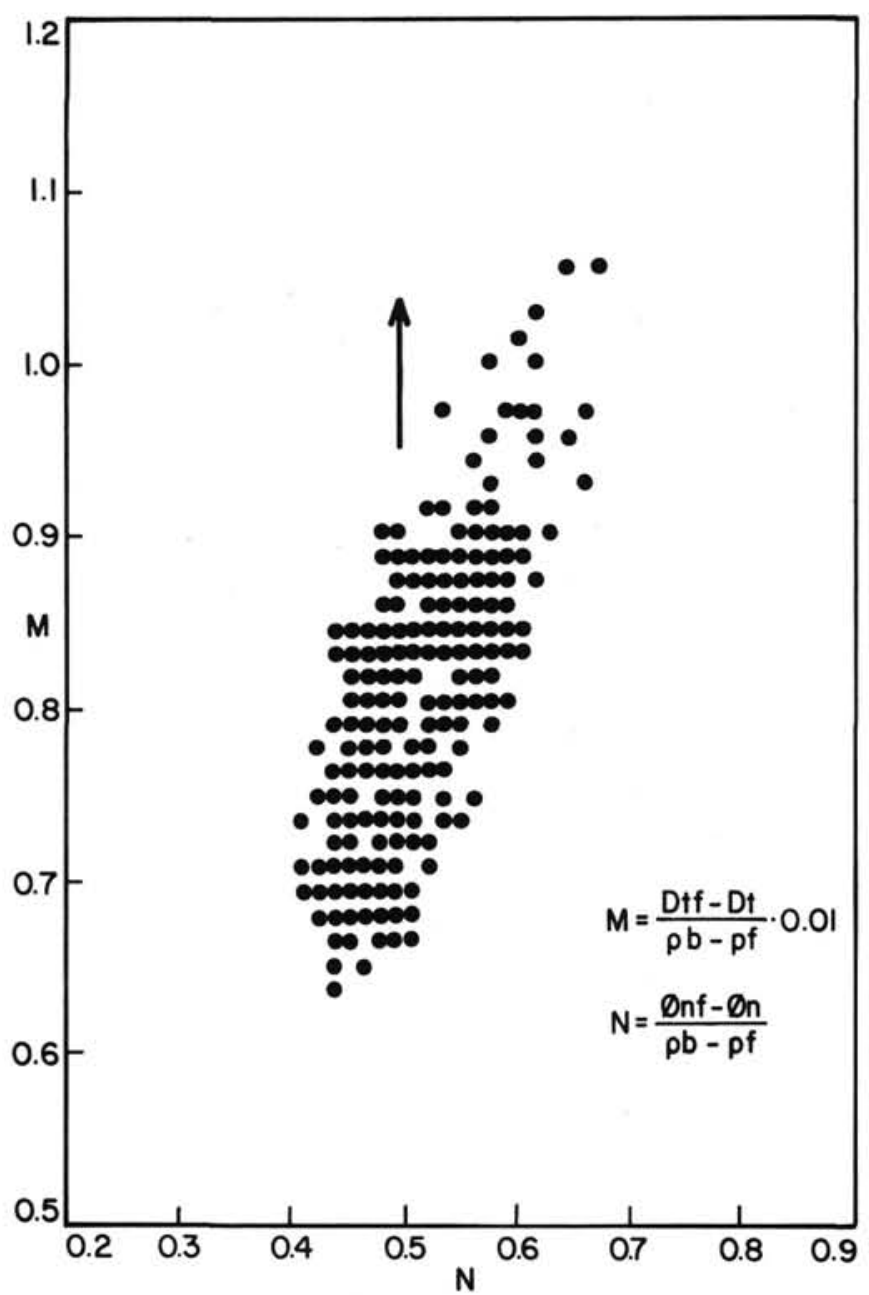

Figure 12. M-N plot in the basement interval from 464 to $776 \mathrm{mbsf}$. The fracture-porosity trend indicated by the arrow suggests that the response of the sonic log is less influenced by the presence of fractures and voids than the neutron and density logs.

ity of $13.1 \%$, and a fracture porosity of $5.4 \%$. The average values of velocity and porosity computed for this zone are in perfect agreement with those observed at Hole 417D (Salisbury et al., 1980a, 1980b) in the upper part of the basement.

Fractures are the primary channel for hydrothermal circulation in oceanic basalts; the extended alteration observed at Hole 418A plays an important role in the evolution of the oceanic crust by reducing the degree of interconnection of the pore space and, consequently, the permeability and convective flow. An estimate of the degree of interconnection of porosity can be obtained from Archie's (1942) formula

$$
F=a / \phi^{m},
$$

where $a$ is an empirical constant, $m$ is the cementation factor, and $F$ is the formation factor, defined as

$$
F=\mathrm{Ro} / \mathrm{Rw},
$$

where Ro is the resistivity of the formation saturated with pore water with a resistivity of $\mathrm{Rw}=0.18 \mathrm{ohm}-\mathrm{m}$ at $24^{\circ} \mathrm{C}$, which corresponds to a salinity of $36,700 \mathrm{ppm}$ (J. Gieskes, pers. comm., 1985).

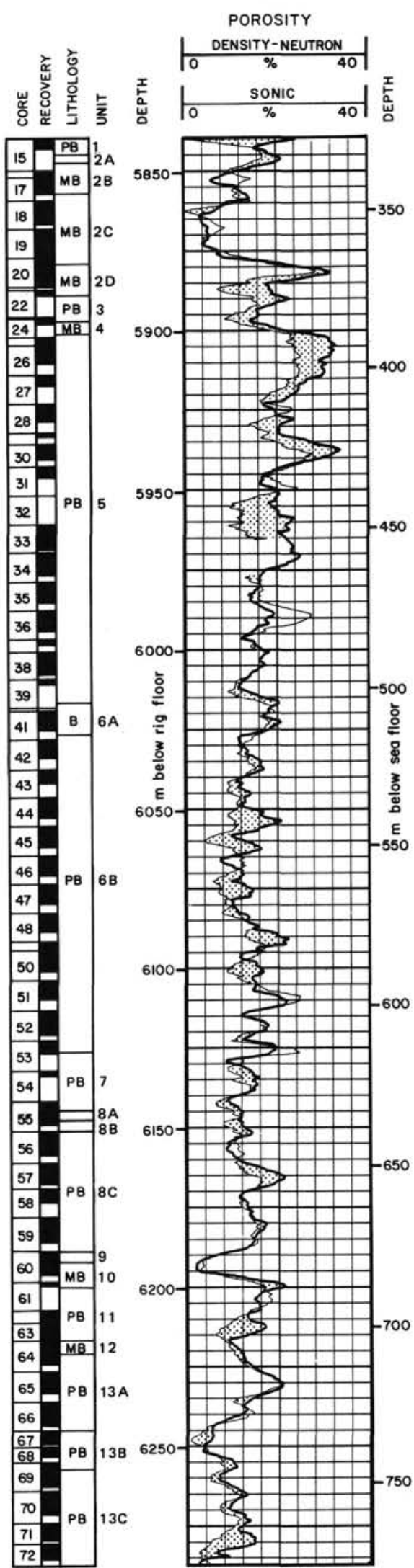

Figure 13. Density-neutron porosity vs. sonic-computed porosity as a function of depth at Hole 418A. Both curves are corrected for smectite content and smoothed by using a 31-point running average (5-m depth interval). $\mathrm{PB}=$ pillow basalt; $\mathrm{MB}=$ massive basalt; $\mathrm{B}=$ breccia. 


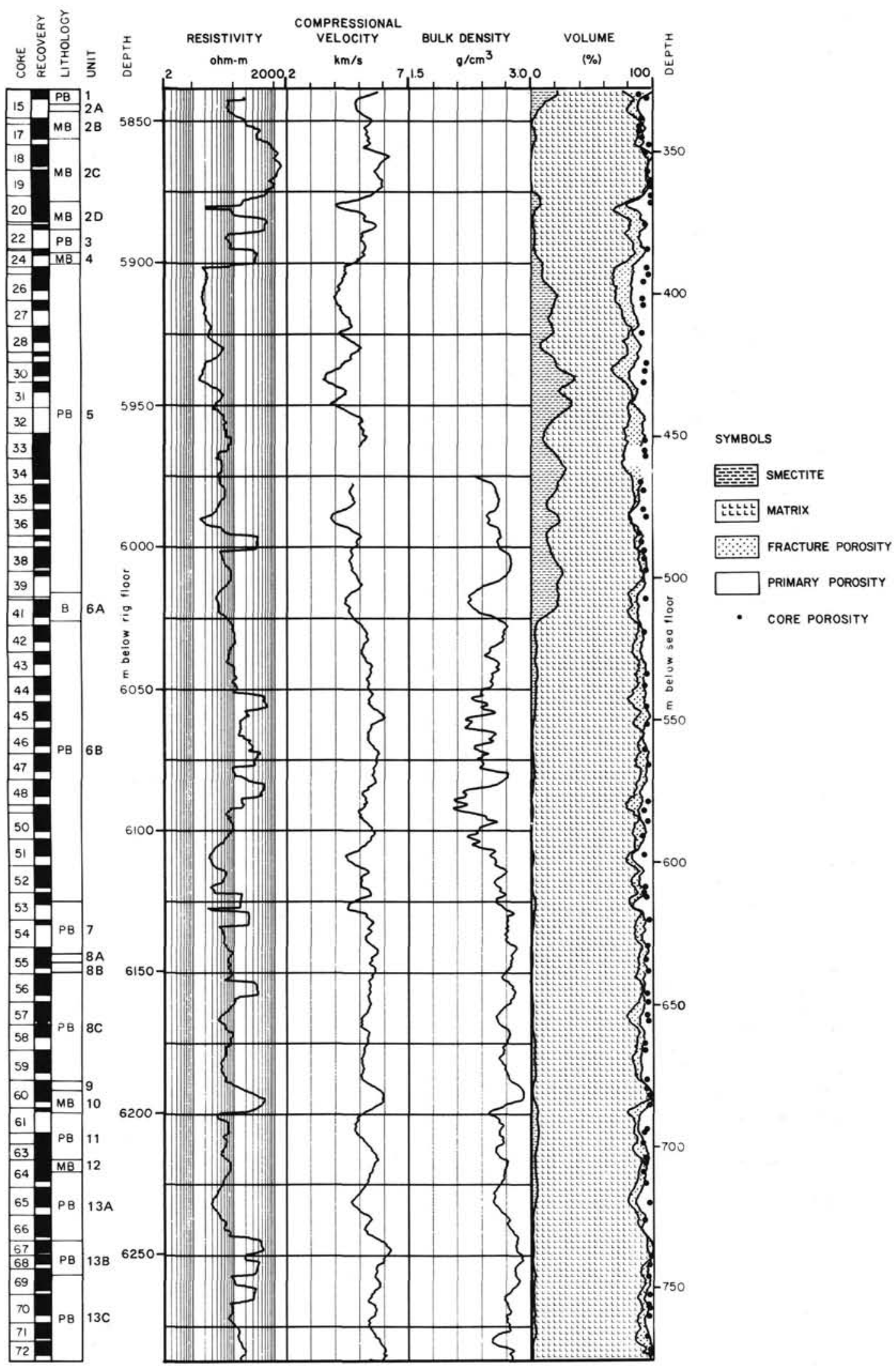

Figure 14. Summary of physical properties of basaltic rocks computed from logs at Hole 418A. Smectite volume calculated from gamma ray; total porosity from density-neutron combination after calibration and correction for smectite content; and primary porosity computed from sonic log. Curves are smoothed by using a 31-point running average (5-m depth interval). $\mathrm{PB}=$ pillow basalt; $\mathrm{MB}=$ massive basalt; $\mathrm{B}=$ breccia. 
Table 3. Average formation properties at Hole 418A.

\begin{tabular}{|c|c|c|c|c|c|}
\hline Property & $\begin{array}{c}324-788 \\
\text { mbsf }\end{array}$ & $\begin{array}{c}\text { Zone } 1 \\
324-388 \\
\text { mbsf }\end{array}$ & $\begin{array}{c}\text { Zone 2 } \\
388-513.7 \\
\text { mbsf }\end{array}$ & $\begin{array}{c}\text { Zone } 3 \\
513.7-788 \\
\text { mbsf }\end{array}$ & Source \\
\hline Total porosity $(\%)$ & 15.1 & 12.6 & 19.7 & 13.1 & $\log s$ \\
\hline Primary porosity $(\%)$ & 9.7 & 8.0 & 13.5 & 7.7 & $\operatorname{logs}$ \\
\hline Fracture porosity $(\%)$ & 5.4 & 4.6 & 6.2 & 5.4 & logs \\
\hline Bulk density $\left(\mathrm{g} / \mathrm{cm}^{3}\right)$ & ${ }^{a} 2.58$ & & $\mathrm{a}_{2.44}$ & 2.72 & $\operatorname{logs}$ \\
\hline Grain density $\left(\mathrm{g} / \mathrm{cm}^{3}\right)$ & 2.95 & & & & cores \\
\hline Velocity $V_{p}(\mathrm{~km} / \mathrm{s})$ & 5.07 & 5.31 & 4.51 & 5.38 & logs \\
\hline Matrix velocity $(\mathrm{km} / \mathrm{s})$ & 6.224 & & & & logs \\
\hline Radioactivity (GAPI units) & 12.8 & 7.6 & 23.4 & 7.3 & $\log s$ \\
\hline Alteration (smectite\%) & 8.8 & 4.9 & 19.3 & 2.3 & $\log s$ \\
\hline Smectite bulk density $\left(\mathrm{g} / \mathrm{cm}^{3}\right)$ & 2.45 & & & & cores \\
\hline Smectite velocity $(\mathrm{km} / \mathrm{s})$ & 4.01 & & & & cores \\
\hline Permeability ( $\mu$ darcies) & $b_{1} \times 10^{-3}$ & & & & cores \\
\hline
\end{tabular}

a From 464 mbsf.

b Johnson (1980a)

In the past, in-situ bulk porosity of basalts from Archie's (1942) formula was estimated using values of $m=1.5-2.2$ computed by assuming $a=1$. Using these parameters, reasonable porosities were obtained at Holes 504B (Becker, 1985; Cann and Von Herzen, 1983) and 395A (Mathews et al., 1984). However, there is no reason to assume that the value $a=1$, which was initially proposed for sedimentary rocks, is valid for these materials. Figure 15 plots data from the upper (Unit 1-Subunit 6A) and lower (Subunits 6B-13C) intervals to determine the parameters $a$ and $m$ for the in-situ data. Contrary to standard assumptions, $a$ is much greater than 1 (see also Salisbury et al., 1980a). The exponent $m$ obtained from the best linear-fit to the data is higher in the upper part of the basement (1.85 against 1.16$)$, indicating a more tortuous interconnection resulting from cementation of most pores and fractures by alteration products. Smectite and carbonate-filled fractures prevail over open fractures in this altered zone (Johnson, 1980b). According to Johnson (1980a), basalts infilled with a large amount of calcium carbonate display permeabilities that are higher than either smectite-rich or fresh basalts $\left(6.1 \times 10^{-14} \mathrm{~cm}^{2}\right)$. Smectite, which is the dominant alteration product at Hole $418 \mathrm{~A}$, is more effective in reducing permeability $\left(0.2 \times 10^{-17} \mathrm{~cm}^{2}\right)$ because of the microscopic size of smectite crystals. A comparison of the values of $m$ obtained using density-neutron and sonic-computed porosities in the lower interval reveals that $m$ is very close (1.16 against 1.26$)$ for similar values of $a$, suggesting once again that the response of the sonic tool is sensitive to most of the fractures and can be used as a good total porosity indicator whenever other porosity logs are not available.

The importance of structure in controlling physical properties is illustrated in Figure 16. Here histograms of velocity, bulk density, total porosity, and resistivity are shown for the different lithologies: massive basalts, basaltic breccia, and smectite-filled (PBI) and less-altered (PBII) pillows. As expected, porosities are highest in the breccia and lowest in the flow. The altered pillows are bimodally distributed, with the average about the same as the less-altered pillows. Bulk density shows the opposite relationship, except that the bulk density of the altered pillows is somewhat lower than expected, due to the presence of smectites. Resistivity in the altered pillows is somewhat lower than that in the unaltered units, possibly due to small amounts of surface conduction in the clays. Resistivity is scattered for the flow, suggesting that it is controlled by details of the pore structure not investigated by the other logs. Compressional-wave velocity is highest in the flows and lowest in the breccia, as expected. The unaltered pillows (see in particular Subunit 13B) also have quite high compressional velocities. This was also observed by Moos et al. (1986) in the uppermost $150 \mathrm{~m}$ of Hole 504B, where pil- lows and flows were discriminated by their $\mathrm{V}_{p} / \mathrm{V}_{s}$ ratios. Similar results are seen at Hole 418A (Moos, this volume). The most striking observation is the large decrease in velocity for the altered pillows in comparison to their unaltered counterparts. This is clear evidence that alteration products replacing basalt decrease the velocity. However, the consequent porosity reduction
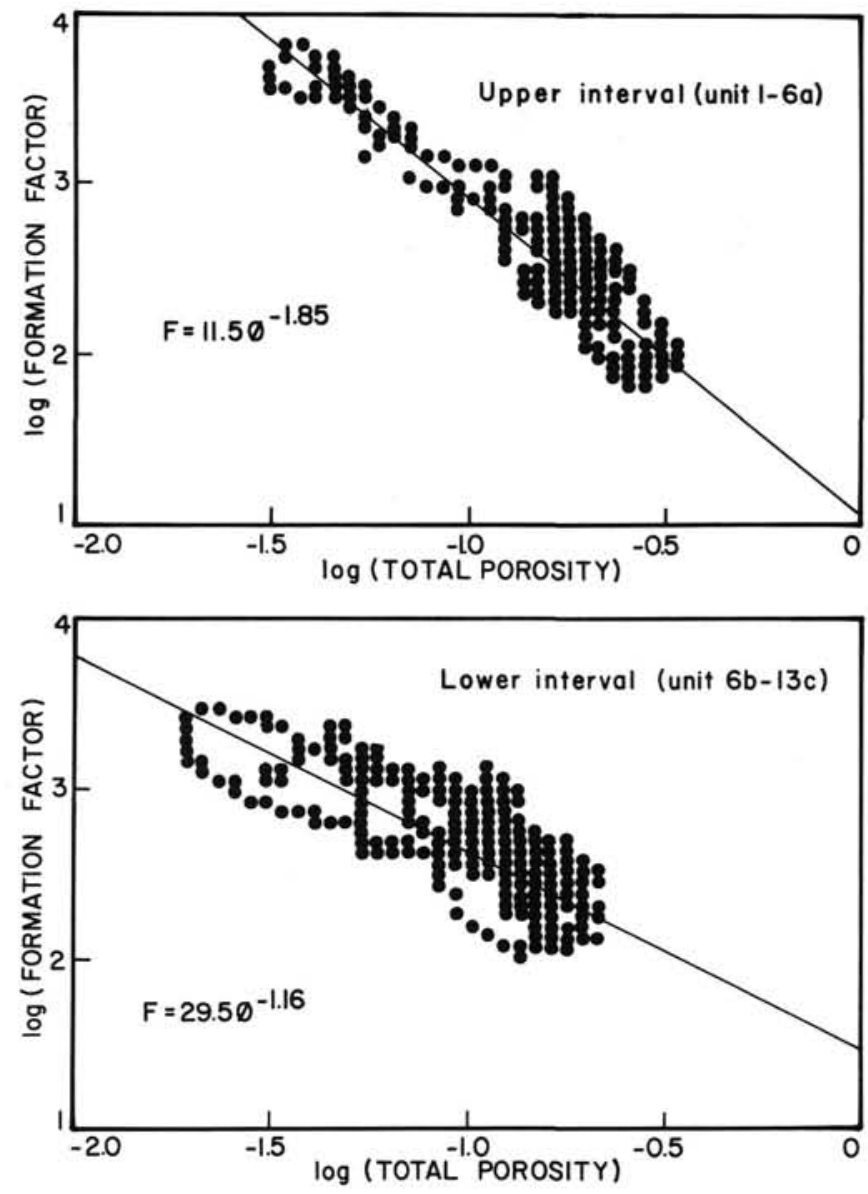

Figure 15. Formation factor vs. total porosity from density-neutron logs in the upper and lower parts of the logged interval. Solid lines represent the best least-squares fit to the logging data. The higher exponent in the upper zone indicates a lower degree of interconnection of the pores, owing to sealing of most pores and fractures by alteration products. 

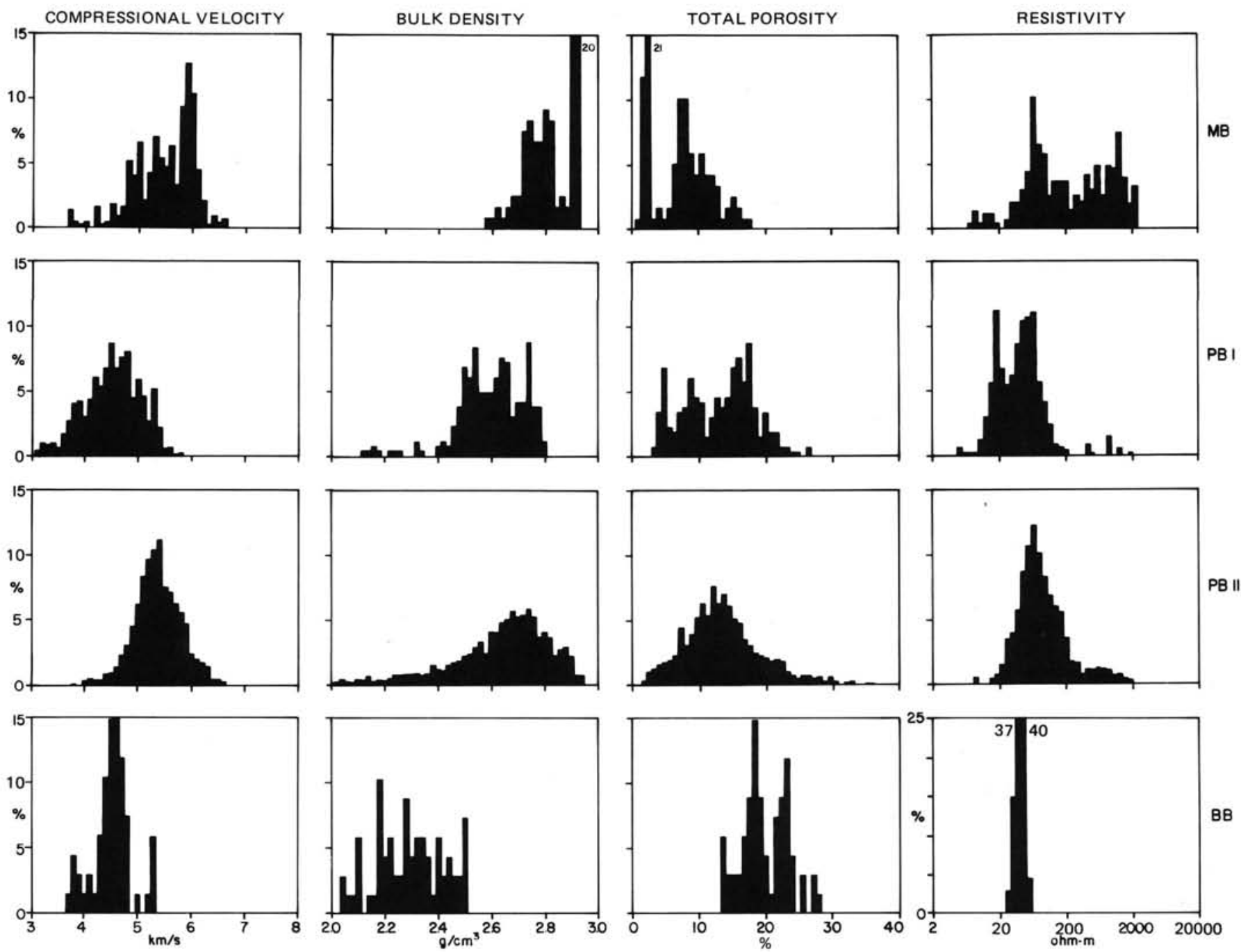

Figure 16. Histograms of basement physical properties at Hole 418A. MB = massive basalts; $\mathrm{PBI}=$ altered pillow basalts $(388-504 \mathrm{mbsf}$ interval); PBII $=$ less altered pillow basalts $(514-788$ mbsf interval); $\mathrm{BB}=$ basaltic breccia .

with crustal age results in a net increase in velocity as alteration and infilling progress, as discussed below.

The smectite log generated by comparing the gamma-ray curve to the core smectite content (Figs. 9 and 14) produces a quantitative estimate of the volume of smectite within these rocks. This measurement accurately reflects the total amount of alteration material added to the crust by interaction with seawater since the basalts were emplaced at the Mid-Atlantic Ridge. By implication, removal of alteration material would return the crust to its original state. There is some uncertainty, however, as to how to replace the volume now filled with smectite. Two approaches can be used to obtain maximum and minimum original porosity limits. The maximum porosity can be found by simply replacing the volume now containing smectite with pore space. This is equivalent to assuming that all of the smectite material was brought into the system by fluid circulation. In this instance, original porosity, $\phi_{1}$, is related to volumetric percentage of smectite $\mathrm{V}_{\text {sme }}$ and present porosity, $\phi$, by

$$
\phi_{1}=\mathrm{V}_{\text {sme }}+\phi .
$$

Alternatively, one can assume that part of the basalt matrix was also replaced by smectite. The basalt volume, $\mathrm{V}_{\mathrm{b}}$, required to produce a given volume of smectite is given by

$$
\mathrm{V}_{\mathrm{b}}=\left(\rho_{\mathrm{sme}} / \rho_{\mathrm{g}}\right) \mathrm{V}_{\mathrm{sme}},
$$

and the original porosity, $\phi_{2}$, computed using this assumption is

$$
\phi_{2}=\left(1-\rho_{\text {sme }} / \rho \mathrm{g}\right) \mathrm{V}_{\text {sme }}+\phi,
$$

where $\rho_{\text {sme }}$ and $\rho_{\mathrm{g}}$ are the density of smectite $\left(2.45 \mathrm{~g} / \mathrm{cm}^{3}\right)$ and fresh basalt $\left(2.95 \mathrm{~g} / \mathrm{cm}^{3}\right)$, respectively. This provides a lower bound on the original porosity. The actual porosity at emplacement will be somewhere between these two estimates, assuming that no other alteration products were added during the aging process. As the total volume of other infilling materials is estimated to be less than $1 \%$ (Salisbury et al., 1980a), this assumption is not unreasonable.

Figure 17 shows the result of this exercise. Porosities have been increased by the addition of the volume fraction that now contains smectite. The upper bound is $\phi_{1}$, assuming all the material was added, and $\phi_{2}$ is the lower bound, assuming that alteration processes also took place in the basalt matrix. The present porosity is $\phi$. The difference ranges from less than $1 \%$ to almost $30 \%$. For the minimum bound the porosity increase is quite modest-no more than $6 \%$ added porosity.

Using the linear porosity-velocity relation shown in Figure 10 $\left(\mathrm{V}_{p}=6.224-0.065 \phi\right)$ we can compute the velocity profile at 


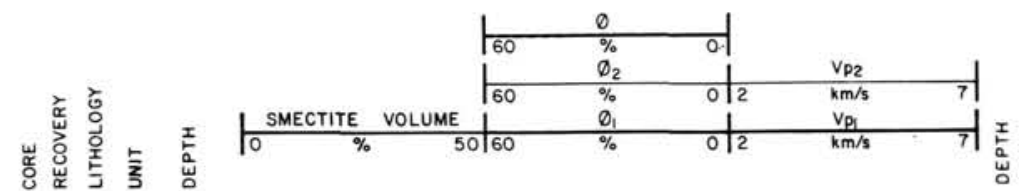

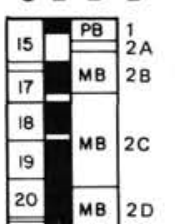

\begin{tabular}{lll}
22 & $\mathrm{~PB}$ & 3 \\
\hline 24 & $\mathrm{MB}$ & \\
\hline
\end{tabular}

26

\begin{tabular}{|l|}
27 \\
\hline 27 \\
\hline
\end{tabular}

28

30 -

${ }_{31}{ }_{\mathrm{PB}}$

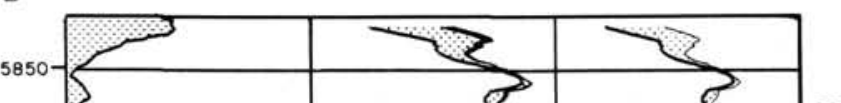

3

34

\begin{tabular}{l}
35 \\
\hline 36 \\
\hline
\end{tabular}

38

39

41 B $6 A$

$6 \mathrm{~A} \cong$
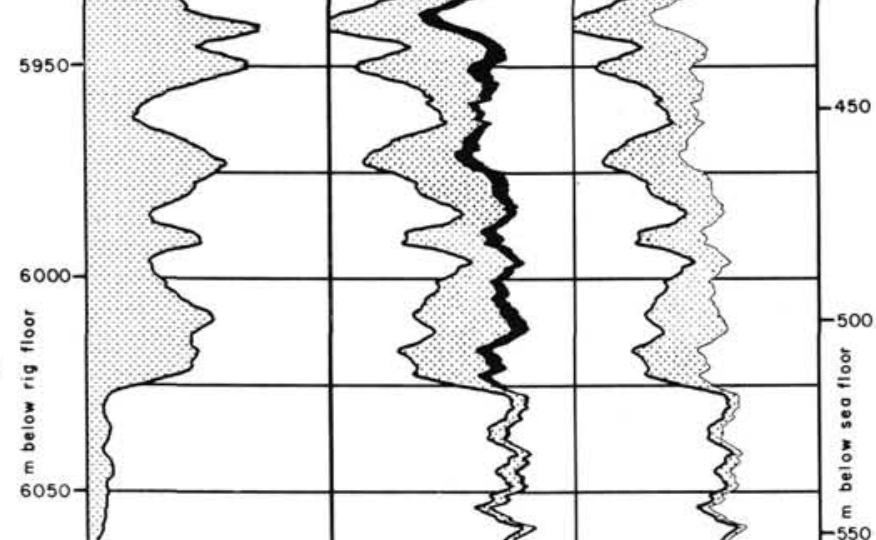

43

\begin{tabular}{l}
44 \\
\hline 45
\end{tabular}

${ }_{48}^{45}=$

47

48

50

51

52

${ }_{54}^{53} \square$

$55-18$

56

57

PB $8 C$

59

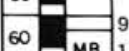

61

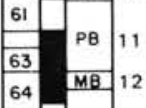

\begin{tabular}{lll}
\hline 65 & & \\
\hline & & \\
\hline
\end{tabular}

66

\begin{tabular}{|l}
66 \\
\hline 67 \\
\hline 68 \\
\hline
\end{tabular}

\begin{tabular}{l}
67 \\
\hline 68 \\
\hline 6
\end{tabular}

69

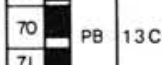

13 B 6250

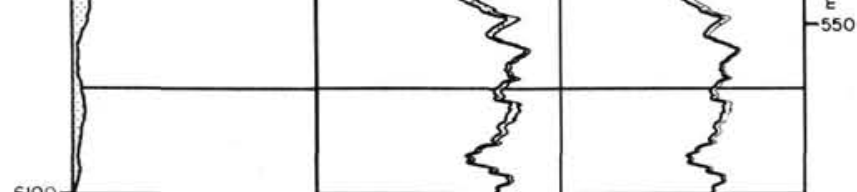

Figure 17. Upper and lower bounds on the original porosity and velocity of the basement obtained assuming that (1) the smectite replaced only part of the original porosity $\left(\phi_{1}, \mathrm{~V}_{p_{1}}\right)$ and (2) the original basalt matrix was also partly replaced by smectite $\left(\phi_{2}, \mathrm{~V}_{p_{2}}\right)$. $\phi$ is the present porosity. The reduced velocities in the $388-514 \mathrm{mbsf}$ interval are consistent with seismic Layer $2 \mathrm{~A}$ velocities measured by Houtz and Ewing (1976). 
the time of emplacement of the rocks from the computed totalporosity curves. The result is displayed in Figure 17. Without the smectites, velocities in zone 2 (388 to $514 \mathrm{mbsf}$ ) range from 3.5 to about $5 \mathrm{~km} / \mathrm{s}$ for the minimum porosity reduction and from 4.5 to less than $2 \mathrm{~km} / \mathrm{s}$ for the maximum porosity assumption. Within the uppermost massive units the velocity is almost unchanged; similarly, the velocity reduction is less than $0.5 \mathrm{~km} / \mathrm{s}$ below the breccia of Subunit $6 \mathrm{~A}$. The reduced velocities are consistent with seismic Layer 2A velocities (e.g., Houtz and Ewing, 1976). By implication, Layer $2 \mathrm{~A}$ was approximately $125 \mathrm{~m}$ thick and could have been as much as $200 \mathrm{~m}$ thick if the uppermost flow units are not areally extensive. Thus, the high sonic compressional-wave velocities now measured in Hole 418A and the absence of seismic Layer $2 \mathrm{~A}$ in profiles run at the site are not due to conditions at the time of emplacement. Rather, the slow addition of smectite by interaction with seawater has reduced the porosity, increasing the velocity and eliminating seismic Layer $2 \mathrm{~A}$ over the $110 \mathrm{Ma}$ since the crust was formed.

The hypothesis that alteration infilling increases seismic velocities and thus eliminates Layer $2 \mathrm{~A}$ as the oceanic crust ages is not new. Schreiber and Fox $(1976,1977)$, Anderson et al. (1985b), and Salisbury et al. (1980b) among others have presented similar proposals. Until now it has not been possible to determine quantitatively whether this hypothesis is reasonable. The calibrated gamma-ray curve (facilitated by the remarkably high core recovery in this well) combined with an accurate velocity-porosity relationship for these rocks allows us to verify this hypothesis for the material at Site 418. As the number of logged basement sites increases, similar calculations can be made elsewhere.

\section{CONCLUSIONS}

We have presented here the results of a comprehensive suite of geophysical log measurements at DSDP Hole 418A. The measurements are of uniformly high quality and include sonic compressional-wave velocity and full waveforms, induction and laterolog resistivity, thermal neutron porosity, gamma-gamma density, natural gamma and spectral natural gamma ray, and caliper log. Prior to analysis the measurements were corrected for borehole effects and calibrated using a carefully selected subset of the core physical-property data. The only suspect data are the density $\log$ in the interval between 539 and $599 \mathrm{mbsf}$, where the wellbore is extremely rough.

Gamma-ray activity in basalts is extremely low except where interaction with seawater increases potassium content. A smectite-content log, calculated from the gamma-ray curve and calibrated using core data, provides an estimate of the in-situ volume percentage of this alteration product. Using this curve, the principal components of the in-situ material (that is, basalt matrix, open pores and cracks, and alteration infilling) were determined. Using the fact that sonic velocity is not very sensitive to voids and fractures with size and spacing approaching the sonic wavelength, the porosity was further broken down into primary, or matrix, porosity and secondary, or fracture, porosity.

Massive basalts in the uppermost $64 \mathrm{~m}$ of basement are unaltered and have high $(>5.0 \mathrm{~km} / \mathrm{s})$ velocities and low porosities $(2 \%$ to $10 \%)$. Resistivities in this interval are above 200 ohm-m. A 137-m-thick highly altered pillow and breccia unit just below the uppermost flow units is more porous (from $5 \%$ to $25 \%$ ), has much lower velocities ( 3.5 to $5 \mathrm{~km} / \mathrm{s}$ ), and contains as much as $40 \%$ smectite by volume. The remainder of the hole is relatively unaltered. Pillows, which compose most of the lowermost interval, have porosities from $5 \%$ to $20 \%$, velocities from 5 to 5.5 $\mathrm{km} / \mathrm{s}$, and resistivities between 20 and $200 \mathrm{ohm}-\mathrm{m}$.

The relatively high compressional-wave velocities throughout the basement interval confirm the Houtz and Ewing (1976) hypothesis that Layer $2 \mathrm{~A}$ is absent in old oceanic crust. The high degree of smectite infilling demonstrates that this is due to alter- ation as the crust ages, as first suggested by Schreiber and Fox $(1976,1977)$. By replacing the smectite component by an appropriate amount of original pore space, we demonstrate that velocities shortly after formation of this crust were substantially lower, and that this hypothesis can be supported quantitatively by physical-properties results.

\section{ACKNOWLEDGMENTS}

We wish to thank the Captain and the crew of JOIDES Resolution and drilling superintendent $\mathrm{G}$. Foss for their assistance during the logging operations and J. Skelly of Houston Schlumberger Offshore for operating the logging tools.

One of the authors (C. B.) wishes to thank D. Goldberg, M. Lovell, and A. Malinverno for useful discussions and comments during the course of this study. J. Daniels, K. Kastens, M. Mathews, M. Salisbury, and J. Scott critically reviewed the manuscript, giving many useful suggestions.

\section{REFERENCES}

Anderson, R. N., O'Malley, H., and Newmark, R. L., 1985a. Use of geophysical logs for quantitative determination of fracturing, alteration, and lithostratigraphy in the upper oceanic crust, Deep Sea Drilling Project Holes 504B and 556. In Anderson, R. N., Honnorez, J., Becker, K., et al., Init. Repts. DSDP, 83: Washington (U.S. Govt. Printing Office), 443-478.

Anderson, R. N., Zoback, M. D., Hickman, S. H., and Newmark, R. L., 1985b. Permeability versus depth in the upper oceanic crust: in situ measurements in Deep Sea Drilling Project Hole 504B, eastern equatorial Pacific. In Anderson, R. N., Honnorez, J., Becker, K., et al., Init. Repts. DSDP, 83: Washington (U.S. Govt. Printing Office), 429-442.

Archie, G. E., 1942. The electrical resistivity $\log$ as an aid in determining some reservoir characteristics. Pet. Tech., 5:1-8.

Becker, K., 1985. Large-scale electrical resistivity and bulk porosity of the oceanic crust, Deep Sea Drilling Project Hole 504B, Costa Rica Rift. In Anderson, R. N., Honnorez, J., Becker, K., et al., Init. Repts. DSDP, 83: Washington (U.S. Govt. Printing Office), 419427.

Cann, J. R., and Von Herzen, R. P., 1983. Downhole logging at Deep Sea Drilling Project Sites 501, 504, and 505, near the Costa Rica Rift. In Cann, J. R., Langseth, M. G., Honnorez, J., Von Herzen, R. P., White, S. M., et al., Init. Repts. DSDP, 69: Washington (U.S. Govt. Printing Office), 281-299.

Christensen, N. I., Blair, S. C., Wilkens, R. H., and Salisbury, M. H., 1980. Compressional wave velocities, densities, and porosities of basalts from Holes 417A, 417D, and 418A, Deep Sea Drilling Project Legs 51-53. In Donnelly, T., Francheteau, J., Bryan, W., Robinson, P., Flower, M., Salisbury, M., et al., Init. Repts. DSDP, 51, 52, 53, Pt. 2: Washington (U.S. Govt. Printing Office), 1467-1471.

Christensen, N. I., and Salisbury, M. H., 1975. Structure and constitution of the lower oceanic crust. Rev. Geophys. Space Phys., 13:5786.

Edmunson, H., and Raymer, L. L., 1979. Radioactive logging parameters for common minerals. Log Analyst, 20(5):38.

Emmermann, R., and Puchelt, H., 1980. Major and trace element chemistry of basalts from Holes 417D and 418A, Deep Sea Drilling Project Legs 51-53. In Donnelly, T., Francheteau, J., Bryan, W., Robinson, P., Flower, M., Salisbury, M., et al., Init. Repts. DSDP, 51, 52, 53, Pt. 2: Washington (U.S. Govt. Printing Office), 9871000 .

Flower, M.F.J., Ohnmacht, W., Robinson, P. T., Marriner, G., and Schmincke, H.-U., 1980. Lithologic and chemical stratigraphy at Deep Sea Drilling Project Sites 417 and 418. In Donnelly, T., Francheteau, J., Bryan, W., Robinson, P., Flower, M., Salisbury, M., et al., Init. Repts. DSDP, 51, 52, 53, Pt. 2: Washington (U.S. Govt. Printing Office), 939-956.

Hamano, Y., 1980. Physical properties of basalts from Holes 417D and 418A. In Donnelly, T., Francheteau, J., Bryan, W., Robinson, P., Flower, M., Salisbury, M., et al., Init. Repts. DSDP, 51, 52, 53, Pt. 2: Washington (U.S. Govt. Printing Office), 1457-1466.

Houtz, R., and Ewing, J., 1976. Upper crustal structure as a function of plate age. J. Geophys. Res., 81:2490-2498.

Humphris, S. E., Thompson, R. N., and Marriner, G. F., 1979. The mineralogy and geochemistry of basalt weathering, Holes 417A and 
418A. In Donnelly, T., Francheteau, J., Bryan, W., Robinson, P., Flower, M., Salisbury, M., et al., Init. Repts. DSDP, 51, 52, 53, Pt. 2: Washington (U.S. Govt. Printing Office), 1201-1217.

Hyndman, R. D., Christensen, N. I., and Drury, M. J., 1984. The physical properties of basalt core samples from Deep Sea Drilling Project Leg 78B Hole 395A. In Hyndman, R. D., Salisbury, M. H., et al., Init. Repts. DSDP, 78B: Washington (U.S. Govt. Printing Office), 801-810.

Johnson, D. M., 1980a. Fluid permeability of oceanic basalts. In Donnelly, T., Francheteau, J., Bryan, W., Robinson, P., Flower, M., Salisbury, M., et al., Init. Repts. DSDP, 51, 52, 53, Pt. 2: Washington (U.S. Govt. Printing Office), 1473-1477.

1980b. Crack distribution in the upper oceanic crust and its effects upon seismic velocity, seismic structure, formation permeability, and fluid circulation. In Donnelly, T., Francheteau, J., Bryan, W., Robinson, P., Flower, M., Salisbury, M., et al., Init. Repts. $D S D P, 51,52,53$, Pt. 2: Washington (U.S. Govt. Printing Office), 1479-1490.

Kirkpatrick, J. R., 1979a. Results of downhole geophysical logging Hole 396B, DSDP Leg 46. In Dmitriev, L., Heirtzler, J., et al., Init. Repts. DSDP, 46: Washington (U.S. Govt. Printing Office), 401407.

$1979 \mathrm{~b}$. The physical state of the oceanic crust: Results of downhole geophysical logging in the Mid-Atlantic Ridge at $23^{\circ} \mathrm{N} . J$. Geophys. Res., 84:178-188.

Lysne, P., in press. Analysis of neutron-porosity-log uncertainties: Ocean Drilling Program Hole 642E. In Eldholm, O., Thiede, J., et al., Proc. ODP, Sci. Results: College Station, TX (Ocean Drilling Program).

Mathews, M., Salisbury, M. H., and Hyndman, R. D., 1984. Basement logging on the Mid-Atlantic Ridge, Deep Sea Drilling Project Hole 395A. In Hyndman, R. D., Salisbury, M. H., et al., Init. Repts. DSDP, 78B: Washington (U.S. Govt. Printing Office), 717-730.

Mathews, M. A., Scott, J. H., and LaDelfe, C. M., 1985. Test pits for calibrating well logging equipment in fractured hard-rock environment. Trans. SPWLA Annu. Logging Symp., 26:Pap. S.

Mevel, C., 1980. Mineralogy and chemistry of secondary phases in low temperature altered basalts from Deep Sea Drilling Project Legs 51, 52, and 53. In Donnelly, T., Francheteau, J., Bryan, W., Robinson, P., Flower, M., Salisbury, M., et al., Init. Repts. DSDP, 51, 52, 53, Pt. 2: Washington (U.S. Govt. Printing Office), 1299-1318.

Moos, D., Goldberg, D., Hobart, M. A., and Anderson, R. N., 1986. Elastic-wave velocities in Layer $2 \mathrm{~A}$ from full waveform sonic logs at Hole 504B. In Leinen, M., Rea, D. K., et al., Init. Repts. DSDP, 92: (U.S. Govt. Printing Office), 563-570.

Moos, D., and Zoback, M. D., 1983. In-situ studies of velocity in fractured crystalline rocks. J. Geophys. Res., 80:2345-2358.

Pertsev, N. N., and Rusinov, V. L., 1980. Mineral assemblages and processes of alteration in basalts at Deep Sea Drilling Project Sites 417 and 418. In Donnelly, T., Francheteau, J., Bryan, W., Robinson, P., Flower, M., Salisbury, M., et al., Init. Repts. DSDP, 51, 52, 53, Pt. 2: Washington (U.S. Govt. Printing Office), 1219-1242.

Pritchard, R. G., 1980. Alteration of basalts from Deep Sea Drilling Project Legs 51, 52, and 53, Holes 417A and 418A. In Donnelly, T., Francheteau, J., Bryan, W., Robinson, P., Flower, M., Salisbury, M., et al., Init. Repts. DSDP, 51, 52, 53, Pt. 2.: Washington (U.S. Govt. Printing Office), 1185-1199.

Rusinov, V. L., Laputina, I. P., Muravitskaja, G. N., Zvjagin, B. B., and Gradusov, B. P., 1980. Clay minerals in basalts from Deep Sea Drilling Project Sites 417 and 418. In Donnelly, T., Francheteau, J., Bryan, W., Robinson, P., Flower, M., Salisbury, M., et al., Init. Repts. DSDP, 51, 52, 53, Pt. 2.: Washington (U.S. Govt. Printing Office), $1265-1272$.
Salisbury, M. H., Christensen, N. I., Becker, K., and Moos, D., 1985. The velocity structure of Layer 2 at Deep Sea Drilling Site 504 from logging and laboratory experiments. In Anderson, R. N., Honnorez, J., Becker, K., et al., Init. Repts. DSDP, 83: Washington (U.S. Govt. Printing Office), 529-539.

Salisbury, M. H., Donnelly, T., and Francheteau, J., 1980a. Geophysical logging in Deep Sea Drilling Project Hole 417D. In Donnelly, T., Francheteau, J., Bryan, W., Robinson, P., Flower, M., Salisbury, M., et al., Init. Repts. DSDP, 51, 52, 53, Pt. 2: Washington (U.S. Govt. Printing Office), 705-713.

Salisbury, M. H., Stephen, R., Christensen, N. I., Francheteau, J., Hamano, J., Hobart, M., and Johnson, D., 1980b. The physical state of the upper levels of Cretaceous oceanic crust from the results of logging, laboratory studies, and the oblique seismic experiment at Deep Sea Drilling Project Sites 417 and 418. In Donnelly, T., Francheteau, J., Bryan, W., Robinson, P., Flower, M., Salisbury, M., et al., Init. Repts. DSDP, 51, 52, 53, Pt. 2: Washington (U.S. Govt. Printing Office), 1579-1597.

Scarfe, C. M., 1980. Secondary minerals in some basaltic rocks from Deep Sea Drilling Project Legs 52 and 53, Hole 418A. In Donnelly, T., Francheteau, J., Bryan, W., Robinson, P., Flower, M., Salisbury, M., et al., Init. Repts. DSDP, 51, 52, 53, Pt. 2: Washington (U.S. Govt. Printing Office), 1243-1252.

Schlumberger, Inc., 1972a. Log Interpretation: Vol. 1, Principles: New York (Schlumberger).

1972b. The Essentials of Log Interpretation Practice: France (Services Techniques Schlumberger).

1985. Log Interpretation Charts: New York (Schlumberger)

Schreiber, E., and Fox, P. J., 1976. Compressional wave velocities and mineralogy of fresh basalts from the FAMOUS area and the Oceanographer Fracture zone and the texture of Layer $2 \mathrm{~A}$ of the oceanic crust. J. Geophys. Res., 81:4071-4076.

1977. Density and P-wave velocity of rocks from the FAMOUS region and their implication to the structure of the oceanic crust. Geol. Soc. Am. Bull., 88:600-608.

Serra, O., 1984. The Fundamentals of Log Interpretation: Amsterdam (Elsevier).

Shipboard Scientific Parties, 1980a. Site 417. In Donnelly, T., Francheteau, J., Bryan, W., Robinson, P., Flower, M., Salisbury, M., et al., Init. Repts. DSDP, 51, 52, 53, Pt. 1: Washington (U.S. Govt. Printing Office), 23-350.

1980b. Site 418. In Donnelly, T., Francheteau, J., Bryan, W., Robinson, P., Flower, M., Salisbury, M., et al., Init. Repts. DSDP, 51, 52, 53, Pt. 1: Washington (U.S. Govt. Printing Office), 351-627.

Shipboard Scientific Party, 1986. Site 418A: Bermuda Rise. In Salisbury, M. H., Scott, J. H., et al., Proc. ODP, Init. Repts., 102: College Station, TX (Ocean Drilling Program), 95-149.

Storzer, D., and Solo, M., 1979. Fission track age of magnetic anomaly M-Zero and some aspects of sea-water weathering. In Donnelly, T., Francheteau, J., Bryan, W., Robinson, P., Flower, M., Salisbury, M., et al., Init. Repts. DSDP, 51, 52, 53, Pt. 2: Washington (U.S. Govt. Printing Office), 1129-1134.

Toksöz, N., Cheng, C. H., and Timur, A., 1976. Velocities of seismic waves in porous rocks. Geophysics, 41:621-645.

Wyllie, M.R.J., Gregory, A. R., and Gardner, G.H.F., 1956. Elastic wave velocities in heterogeneous and porous media. Geophysics, 21: 41-70.

tic wave velocities in porous media. Geophysics, 23:459-493.

Date of initial receipt: 9 December 1986

Date of acceptance: 25 March 1987

Ms 102B-113 